\title{
GELIJKHEID EN VERSCHIL VAN VOORVOEGSELS IN INDONESISCHE TALEN.
}

DOOR

\author{
R. A. KERN.
}

In de Indonesische talen zijn vele namen van planten met een voorvoegsel samengesteld, als hoedanig een consonant met $a$-vocaal of, om een aan de Javaansche spraakkunst ontleenden term die het verschijnsel beter kenschetst te gebruiken, aksara lěgěna: $k a-, p a-, l a-$, enz. In een kleine minderheid van gevallen is de aksara drager van een andere vocaal: $i(e)$ of $o e(o)$.

Het plantkundig woordenboek van de Clercq $^{1}$ ) bevat een zeer groot aantal namen van planten, die in Nederlandsch-Indië inheemsch of inheemsch geworden zijn. Eerst wordt de Latijnsche naam gegeven en dan volgen een aantal namen in Indonesische talen. Men weet dus dat deze bijeen behooren wat vergelijking en identificatie vergemakkelijkt.

Namen van dieren, ook wel van andere zaken, o.a. gebruiksvoorwerpen, zijn op dezelfde wijze van een aksara lěgĕna als aanwijzer voorzien. Er ontbreekt echter een dierkundig woordenboek als de Clercq voor de planten vervaardigde. Bij deze namen staan dus alleen de woordenboeken ter beschikking die wel eens den wetenschappelijken naam geven, maar doorgaans niet. De omschrijvingen die gegeven worden - uit den aard der zaak zijn meestal geen vertalingen te geven - zijn voor vergelijking en identificatie onvoldoende. Vandaar dat ik mij in de volgende bladzijden tot de planten beperkt heb.

De Clercq's woordenboek behandelt alleen de planten van Nederlandsch-Indië. Het noodzakelijke complement zou een gelijk boek voor de Filippijnen moeten zijn, maar dit bestaat, zoover mij bekend, niet. Hier moet men zich dus met de woordenboeken behelpen met alle onzekerheden daaraan verbonden. Wanneer dus in onderstaande woordenlijst slechts weinig namen in Filippijnsche talen opgenomen zijn, wijte men dit aan genoemde omstandigheid. Er mag niet uit besloten worden dat het verschijnsel der aanwijzers in de Filippijnsche talen minder frequent zou zijn, dit is geenszins het geval. Voor

1) F. S. A. de Clercq, Nieuw plantkundig woordenboek van NederlandschIndië. - Amsterdam 1909. 
het Tagalog heb ik mijn wetenschap geput uit het woordenboek van de Noceda en enkele andere gegevens, voor het Bisaya uit het woordenboek van de la Encarnacion ${ }^{1}$ ).

Wat het gebied van Nederlandsch-Indië betreft, ruimt de Clercq een ruime plaats in aan namen in Bataviaasch Maleisch, het Maleisch van Menado, het Maleisch der Molukken e.d. Ik heb deze namen buiten beschouwing gelaten omdat men hier met uit verschillende talen getrokken mengelmoezen te doen heeft, vaak nog verbasterd en verhaspeld. 't Zelfde geldt van andere namen uit den Grooten Oost, men twijfelt telkens met welke taal men te doen heeft en of zij door vreemden mond is overgebracht. Het bezwaar ten aanzien van de talen der Filippijnen waarvan ik zooeven repte, wordt eenigermate hierdoor ondervangen dat wij omtrent plantennamen uit de Minahasa, waar sub-Filippijnsche talen gesproken worden zeer goed zijn ingelicht door het uitvoerige werk van Koorders over de flora van dat gebied ${ }^{2}$ ), waarvan ook de Clercq voor zijn woordenboek profijt heeft getrokken, nog vermeerderd met gegevens uit het Tontemboan'sch woordenboek van Schwarz. Koorders onderscheidt de inheemsche talen in: Tontemboan, Tomboeloe, Tooelooer, Tonsea, Ratahan en Bentenan'sch, Tonsawang'sch, Bantik'sch. De Adriani's hebben in de "Hoofdstukken uit de spraakkunst van het Tontemboan'sch" ('s-Gravenhage 1908) deze talen als volgt gegroepeerd: Bantik'sch en Bentenan'sch behooren bij de Sangir-Talaut-groep, zijn dus Filippijnsch. Tot het Tomboeloe'sch behooren Tonsea en Tondano, tot het Tontemboan'sch het Tonsawang'sch. Het Tondano'sch is wat door Koorders Tooelooer wordt genoemd. Het Tomohon'sch (Tom.) behoort ook tot het Tomboeloe'sch. In de woordenlijst heb ik de namen opgegeven als door de Clercq vermeld, soms, waar dat mogelijk was, naar het $\mathrm{Wb}$. verbeterd. Tooelooer ( $\mathrm{Tl}$.) en Tonsea (Ts.) worden dus onder Tomboeloe'sch, Tonsawang (Tsw.) wordt onder Tontemboan'sch genoemd. Voor deze laatste taal geeft de Clercq den naam Tompakěwa. Schwarz heeft echter aangetoond dat dit een spotnaam is en de juiste naam Tontemboan ${ }^{3}$ ), welke dus in

\footnotetext{
1) J. de Noceda y el P. Pedro de Sanlucar, Vocabulario de la lengua Tagalog. - Manila, Reimpreso, 1860.

P. J. F de la Encarnacion, Diccionario Bisaya-Español, 3de druk. - Manila 1885.

2) S. H. Koorders, Verslag eener botanische dienstreis door de Minahasa (Mededeelingen van 's Lands Plantentuin XIX). - Batavia 1898.

$\left.{ }^{3}\right) J$. A. F. Schwars, De benamingen Tontemboan en Tompakěwa, in: Tijdschrift Batav. Gen. XLVI, 108 v.v.
} 
de woordenlijst gebruikt wordt. Het Ponosakan'sch waarvan de Clercq enkele voorbeelden geeft, voegen de Adriani's bij het Bolaang-Mongondow'sch.

Thans moge eerst de vergelijkende woordenlijst een plaats vinden, zij zal gevolgd worden door de aanteekeningen waartoe zij aanleiding geeft. Om haar niet te onhandzaam te maken is zij in tweeën gedeeld : A Namen in eenige westelijke talen, B Namen in sub-Filippijnsche en Filippijnsche talen. De volgnummers van beide lijsten correspondeeren. In de tweede kolom is het volgnummer van de Clercq opgenomen, de Latijnsche namen zijn achterwege gelaten, zij zijn aan de hand der volgnummers in het woordenboek gemakkelijk te vinden. In de Woordenlijst toch is het er om te doen een overzicht van de in Indonesische talen gebruikelijke aanwijzers te geven. Een ririm aantal voorbeelden was hiertoe voldoende. Wie meer wenscht. raadplege de Clercq's woordenboek zelf.

De vocaal $a$ is, ook waar zij in de uitspraak tot ě wordt verdoft, zooals in de derde lettergreep van achteren in Javaansch en Maleisch, $a$ geschreven. In het Karo-Bataksch is de uitspraak soms $a$, soms $\breve{e}$, maar niet onverschillig, dat is in het oog gehouden.

De aksara $h a$ - is in de talen die de $h$ niet uitspreken $a$-geschreven. Verder neme men in aanmerking dat Toba- en Mandailing-Bataksch $h a-=k a$ - in verwante talen. - Het Boegineesch laat de $k$ aan het begin van een woord vaak vallen : uli' $=k u l i t$ - huid, bast, vel. Doch is $k a$ - prefix dan wordt de $k$ bewaard, men vindt dus kalao-lao - in onderscheidene richtingen, op goed geluk gaan, gw. lao - gaan; kalěttu' < *makalěttu' - het einde bereiken, gw. lěttu' - aankomen ; kainrĕngĕng — in schulden zitten, van inrěng, gw. van leenen. De $k$ van den aanwijzer $k a$ - kan wel afvallen : atapang = elders $k a t a p a n g$, de aanwijzer wordt dus niet als voorvoegsel gevoeld maar als deel van het woord beschouwd.

Enkele aanvullingen of verbeteringen van namen die bij de Clercq voorkomen, zijn aan de bekende woordenboeken (wb.) ontleend; v. E. bij Balisch beteekent: R. van Eck, Eerste proeve van een Balineesch-Hollandsch woordenboek. - Utrecht 1876. — E. onder Bataksch is : H. J. Eggink, Angkola- en Mandailing - Bataksch-Nederlandsch Woordenboek, Verh. Batav. Gen. LXXII 5, Bandoeng 1936; Karo J. is: M. Joustra, Karo-Bataksch Woordenboek. - Leiden 1907. Met Hd. bij Dajaksch is het woordenboek van Hardeland bedoeld.

D1. 101. 
A

\begin{tabular}{|c|c|c|c|c|c|c|}
\hline $\begin{array}{l}\text { Door- } \\
\text { loopend } \\
\text { nummer. }\end{array}$ & $\begin{array}{l}\text { Volgnum- } \\
\text { mer wb. } \\
\text { de Clercq. }\end{array}$ & Javaansch. & Soendaasch. & Baliesch. & Maleisch. & $\begin{array}{l}\text { Menang- } \\
\text { kabausch: }\end{array}$ \\
\hline 1 & 3027 & (katjapi) & katjapi & & & \\
\hline 2 & 3262 & mĕnjan & měnjan, & měnjan & kamĕnjan & $\begin{array}{l}\text { koemajan } \\
\text { kamijan } \\
\text { koemojan } \\
\text { koemajen }\end{array}$ \\
\hline 3 & 2358 & $\begin{array}{l}\text { kamoening } \\
\text { koemoening }\end{array}$ & kamoening & $\begin{array}{l}\text { kamoning } \\
\text { kamoening }\end{array}$ & kamoening & kamoeniěng \\
\hline 4 & 135 & $\begin{array}{l}\text { kamiri } \\
\text { miri }\end{array}$ & & kameri & & \\
\hline 5 & 1664 & $\begin{array}{l}\text { kaḍěle } \\
\text { gad̆ěle } \\
\text { ḍĕle }\end{array}$ & kaděle & kaḍĕle & kadělai & \\
\hline 6 & 3313 & katapang & katapang & katapang & katapang & katapeëng \\
\hline 7 & 1961 & $\begin{array}{l}\text { katimaha } \\
\text { katimanga } \\
\text { timaha } \\
\text { timanga }\end{array}$ & & $\begin{array}{l}\text { katimaä } \\
\text { katimaän }\end{array}$ & katimahar & \\
\hline 8 & 3188 & $\begin{array}{l}\text { kapidada } \\
\text { pidada } \\
\text { padada } \\
\text { kadada }\end{array}$ & pidada & pidada & padada & pidada \\
\hline 9 & 1604 & $\begin{array}{l}\text { katjapiring } \\
\text { tjapiring } \\
\text { patjiring }\end{array}$ & katjapiring & djampiring & katjapiring & \\
\hline 10 & 3282 & $\begin{array}{l}\text { kambirit } \\
\text { gambirit } \\
\text { tjambirit } \\
\text { tjampirit } \\
\text { djambirit }\end{array}$ & & & & \\
\hline 11 & 1079 & $\begin{array}{l}\text { karandji } \\
\text { koerandji } \\
\text { parandji }\end{array}$ & $\begin{array}{l}\text { karandji } \\
\text { parandji } \\
\text { randji }\end{array}$ & $\begin{array}{l}\text { kawandji } \\
\text { koewandji }\end{array}$ & karandji & $\begin{array}{l}\text { koeandji } \\
\text { koerandji }\end{array}$ \\
\hline 12 & 1042 & katjoeboeng & koetjoeboeng & katjoeboeng & katjoeboeng & katjoeboeăng \\
\hline 13 & 885 & katoembar & katoentjar & $\begin{array}{l}\text { katoembah } \\
\text { toentjar }\end{array}$ & katoembar & \\
\hline 14 & 2175 & $\begin{array}{l}\text { kaweni } \\
\text { koeweni }\end{array}$ & kaweni & $\begin{array}{l}\text { koeweni } \\
\text { kaweni v. E. }\end{array}$ & & koweni \\
\hline
\end{tabular}


GELIJKHEID EN VERSCHIL VOORVOEGSELS IN INDONESISCHE TALEN. 345

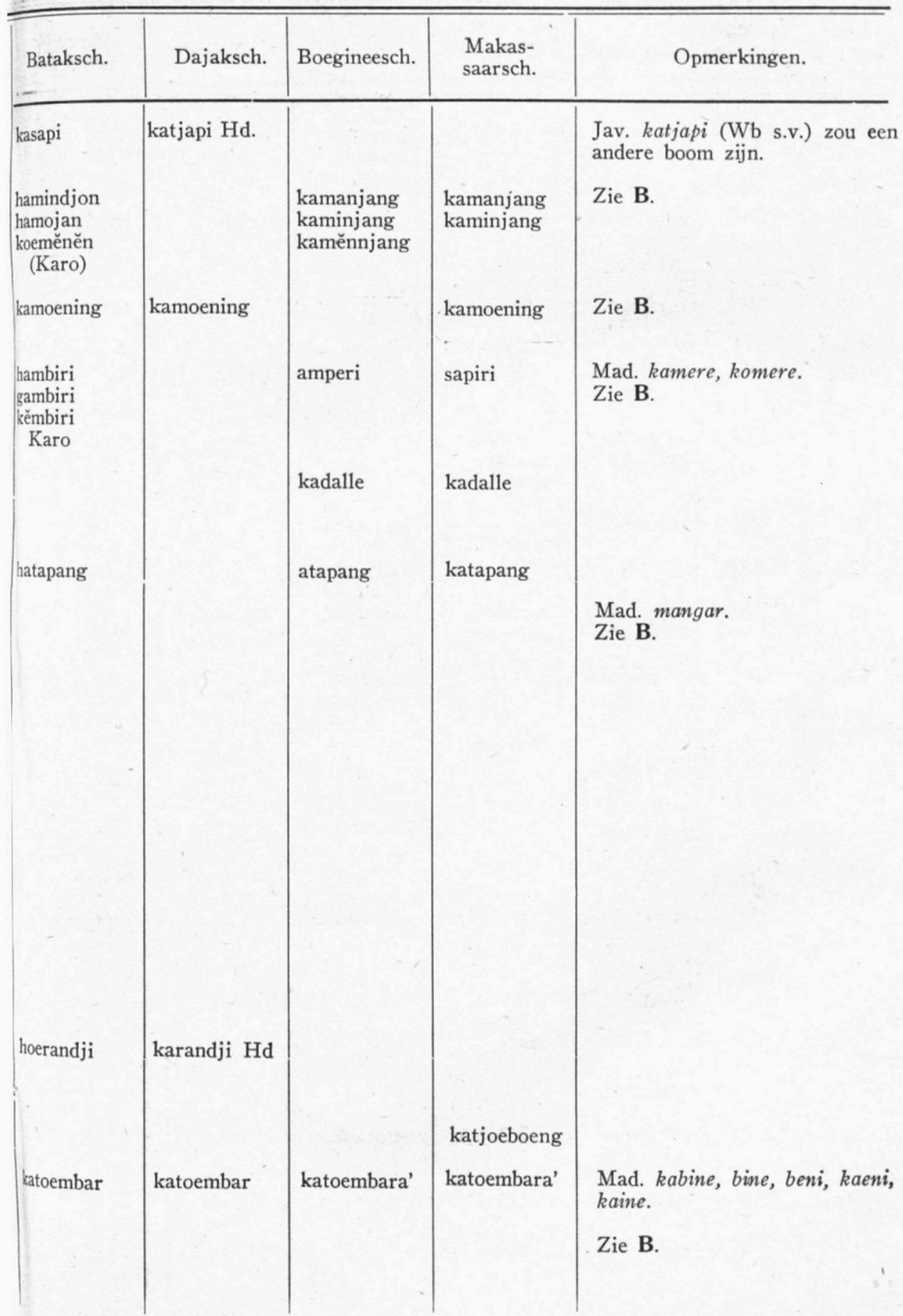


A

\begin{tabular}{|c|c|c|c|c|c|c|}
\hline $\begin{array}{l}\text { Door- } \\
\text { loopend } \\
\text { nummer. }\end{array}$ & $\begin{array}{l}\text { Volgnum- } \\
\text { mer wb. } \\
\text { de Clercq. }\end{array}$ & Javaansch. & Soendaasch. & Baliesch. & Maleisch. & $\begin{array}{l}\text { Menang- } \\
\text { kabausch. }\end{array}$ \\
\hline 15 & 3067 & $\begin{array}{l}\text { kasambi } \\
\text { koesambi }\end{array}$ & kosambi & $\begin{array}{l}\text { koesambi } \\
\text { kasambi } \\
\text { sambi }\end{array}$ & koesambi & \\
\hline 16 & 1296 & $\begin{array}{l}\text { kalajoe } \\
\text { kilajoe } \\
\text { katilajoe }\end{array}$ & lalajoe & kalajoe & kalajoe & kalajau \\
\hline 17 & 830 & $\begin{array}{l}\text { karambil } \\
\text { katjambil }\end{array}$ & . & & kalambir & karambiě \\
\hline 18 & 602 & kanari & kanari & & kanari & . \\
\hline 19 & 1907 & $\begin{array}{l}\text { kalaměta } \\
\text { kalaměnta }\end{array}$ & $\begin{array}{l}\text { kalaměta } \\
\text { lamběta } \\
\text { laměta }\end{array}$ & & & \\
\hline 20 & 1347 & kalesěm & & kalihasěm & & \\
\hline 21 & 152 & & & $\begin{array}{l}\text { kalijombo } \\
\text { laiombo }\end{array}$ & & \\
\hline 22 & .2787 & $\begin{array}{l}\text { kambodja } \\
\text { sambodja }\end{array}$ & $\begin{array}{l}\text { kambodja } \\
\text { sambodja }\end{array}$ & samodja & kambodja & \\
\hline 23 & 829 & kanigara & & $\begin{array}{l}\text { kanigara } \\
\text { tjanigara }\end{array}$ & & \\
\hline 24 & 246 & $\begin{array}{l}\text { kanowa } \\
\text { kaloewa } \\
\text { manoewa } \\
\text { manowa } \\
\text { malowa }\end{array}$ & manowa & & & \\
\hline 25 & 665 & kapaja & 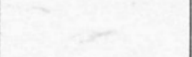 & & kapaja & popaja \\
\hline 26 & 395 & $\begin{array}{l}\text { kapoendoeng } \\
\text { poendoeng }\end{array}$ & kapoendoeng & kapoendoeng & & kapoendoeăng \\
\hline 27 & 1469 & $\begin{array}{l}\text { karoja } \\
\text { koerja }\end{array}$ & & karoja & 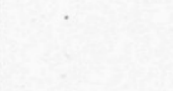 & \\
\hline 28 & 824 & $\begin{array}{l}\text { katělěng } \\
\text { tělěng } \\
\text { mantělěng }\end{array}$ & tělĕng & tělěng & tělang & \\
\hline 29 & 1227 & $\begin{array}{l}\text { katilampa } \\
\text { talilampah }\end{array}$ & katoelampa & katoelampa & & \\
\hline 30 & 2937 & $\begin{array}{l}\text { baḍali } \\
\text { kad̦ali } \\
\text { ḍaii }\end{array}$ & paḍali & . & & \\
\hline
\end{tabular}




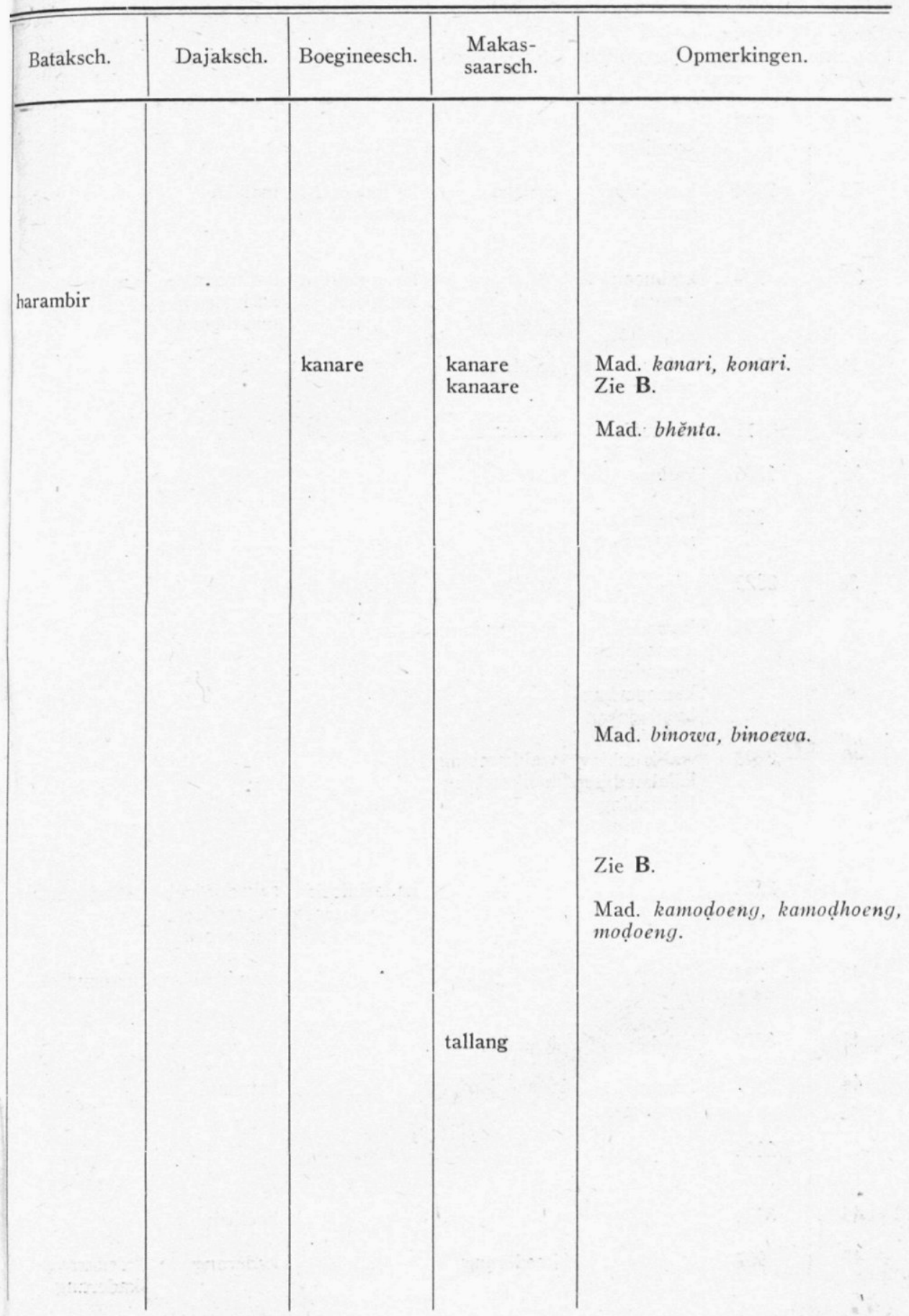




\begin{tabular}{|c|c|c|c|c|c|c|}
\hline $\begin{array}{l}\text { Door- } \\
\text { loopend } \\
\text { nummer. }\end{array}$ & $\mid \begin{array}{c}\text { Volgnum- } \\
\text { mer wb. } \\
\text { de Clercq. }\end{array}$ & Javaansch. & Soendaasch. & Baliesch. & Maleisch. & $\begin{array}{l}\text { Menang- } \\
\text { kabausch. }\end{array}$ \\
\hline 31 & 3467 & $\begin{array}{l}\text { katilĕng } \\
\text { koetilěng }\end{array}$ & & & & \\
\hline 32 & 2684 & $\begin{array}{l}\text { kamalaka } \\
\text { malaka }\end{array}$ & malaka & $\begin{array}{l}\text { kalimaka } \\
\text { kamalaka }\end{array}$ & malaka & \\
\hline 33 & 934 & $\begin{array}{l}\text { katimoen } \\
\text { timoen }\end{array}$ & & $\begin{array}{l}\text { katimoen } \\
\text { antimoen }\end{array}$ & $\begin{array}{l}\text { katimoen } \\
\text { antimoen } \\
\text { mantimoen }\end{array}$ & antimoen \\
\hline 34 & 1146 & $\begin{array}{l}\text { kalalar } \\
\text { palalar }\end{array}$ & polahlar & & . & \\
\hline 35 & 11 & kalampis & kolampis & & & \\
\hline 36 & 1706 & kalinoe & hareno & & & \\
\hline 37 & 122 & $\begin{array}{l}\text { kalantara } \\
\text { salantara }\end{array}$ & 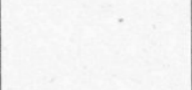 & & & \\
\hline 38 & 2822 & & kadaka & wandaka & & \\
\hline 39 & 2096 & $\begin{array}{l}\text { kamadeh } \\
\text { kamadehan } \\
\text { kamadihan } \\
\text { kamadoehan } \\
\text { kamladehan }\end{array}$ & mangandeuh & & & \\
\hline 40 & 3043 & $\begin{array}{l}\text { walikambing } \\
\text { kalakambing } \\
\text { lakambing } \\
\text { lekambing } \\
\text { clakambing }\end{array}$ & $\begin{array}{l}\text { walikambing } \\
\text { kalikambing }\end{array}$ & & . & \\
\hline 41 & 2222 & & 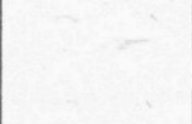 & $\begin{array}{l}\text { kadoekdoek } \\
\text { loeroeloeroek }\end{array}$ & $\begin{array}{l}\text { sakadoedoek } \\
\text { sandoedoek } \\
\text { kadoeroek }\end{array}$ & sikadoedoeă' \\
\hline 42 & 784 & & & & mandikai & kamandiki \\
\hline 43 & 3374 & kalabět & koelabět & & & \\
\hline 44 & 2477 & $\begin{array}{l}\text { kamangi } \\
\text { koemangi }\end{array}$ & & & kamangi & \\
\hline 45 & 2004 & & & & & \\
\hline 46 & 3374 & & & & hoelbah & \\
\hline 47 & 937 & & koedĕrang & & kadĕrang & $\begin{array}{l}\text { koedarang } \\
\text { kaderang }\end{array}$ \\
\hline
\end{tabular}




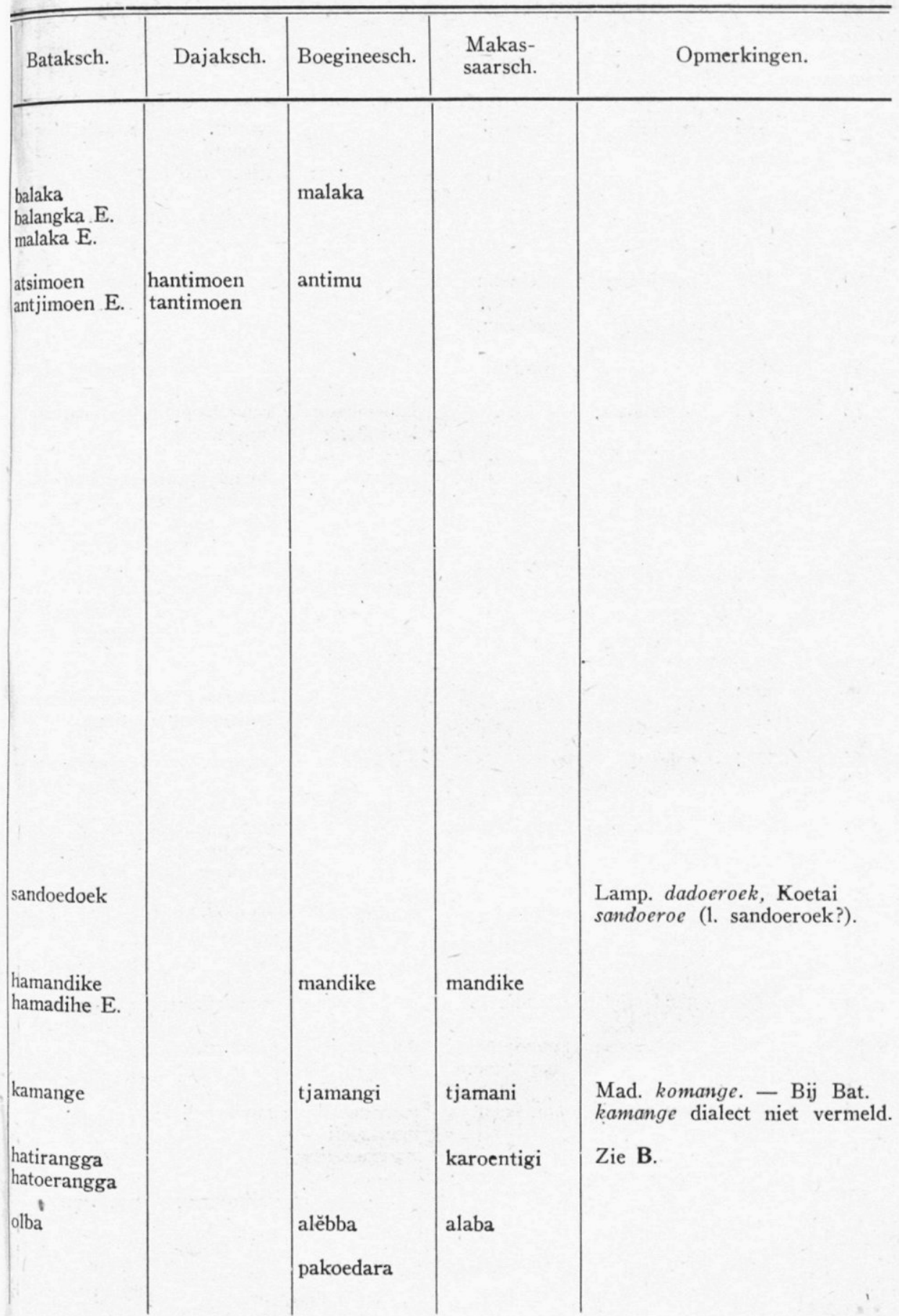




\begin{tabular}{|c|c|c|c|c|c|c|}
\hline $\begin{array}{c}\text { Door- } \\
\text { loopend } \\
\text { nummer. }\end{array}$ & $\mid \begin{array}{l}\text { Volgnum- } \\
\text { mer wb. } \\
\text { de Clercq. }\end{array}$ & Javaansch. & Soendaasch. & Baliesch. & Maleisch. & $\begin{array}{l}\text { Menang- } \\
\text { kabausch. }\end{array}$ \\
\hline 48 & 846 & gambili & koeměli & & $\begin{array}{l}\text { kambili } \\
\text { gombili } \\
\text { (Bandjar) }\end{array}$ & kamili \\
\hline 49 & 3154 & & & & tampinis & $\begin{array}{l}\text { kapini } \\
\text { pindis }\end{array}$ \\
\hline 50 & 2575 & poetjoeng & $\begin{array}{l}\text { patjoeng } \\
\text { pitjoeng } \\
\text { potjoeng }\end{array}$ & & & $\begin{array}{l}\text { kapentjoeăng } \\
\text { kapetjong }\end{array}$ \\
\hline 51 & 2719 & & tjambaj & & & tjambai \\
\hline 52 & 1818 & kroembang & & $\begin{array}{l}\text { kaoembang } \\
\text { koembang }\end{array}$ & $\begin{array}{l}\text { kalambahang } \\
\text { kambahang }\end{array}$ & koembahang \\
\hline 53 & 580 & - & & poenaga & $\begin{array}{l}\text { panaga } \\
\text { banaga } \\
\text { kajoe naga }\end{array}$ & poenaga \\
\hline 54 & 1799 & waroe & waroe & waroe & baroe & \\
\hline 55 & 784 & & & & & $\begin{array}{l}\text { kalambodja } \\
\text { karambodja }\end{array}$ \\
\hline 56 & 2978 & & & & $\begin{array}{l}\text { karamoenting } \\
\text { kamoenting }\end{array}$ & $\begin{array}{l}\text { karamoen- } \\
\text { tiěng }\end{array}$ \\
\hline 57 & 3012 & galagah & & galagah & galagah & $\begin{array}{l}\text { galagah } \\
\text { kalagah }\end{array}$ \\
\hline 58 & 2487 & gandiwoeng & $\begin{array}{l}\text { handiwoeng } \\
\text { liwoeng }\end{array}$ & & $\begin{array}{l}\text { aniboeng } \\
\text { niboeng } \\
\text { njiboeng }\end{array}$ & \\
\hline 59 & 1217 & $\begin{array}{l}\text { ganitri } \\
\text { djanitri } \\
\text { djinitri }\end{array}$ & $\begin{array}{l}\text { ganitri } \\
\text { djanitri }\end{array}$ & ganitri & $\begin{array}{l}\text { gandatěri } \\
\text { ganditěri } \\
\text { ganitri }\end{array}$ & \\
\hline 60 & 489 & gandarija & gandarija & & gandarijah & gandarijah \\
\hline 61 & 1948 & gandaroesa & $\begin{array}{l}\text { gandaroesa } \\
\text { handaroesa }\end{array}$ & $\begin{array}{l}\text { dahoesa } \\
\text { doesa }\end{array}$ & gandaroesa & \\
\hline 62 & 1740 & gandasoeli & gandasoli & $\begin{array}{l}\text { mandasoeli } \\
\text { manasoeli } \\
\text { mandasoeling }\end{array}$ & gandasoeli & 1 \\
\hline 63 & 679 & & & & galinggang & goelinggang \\
\hline
\end{tabular}




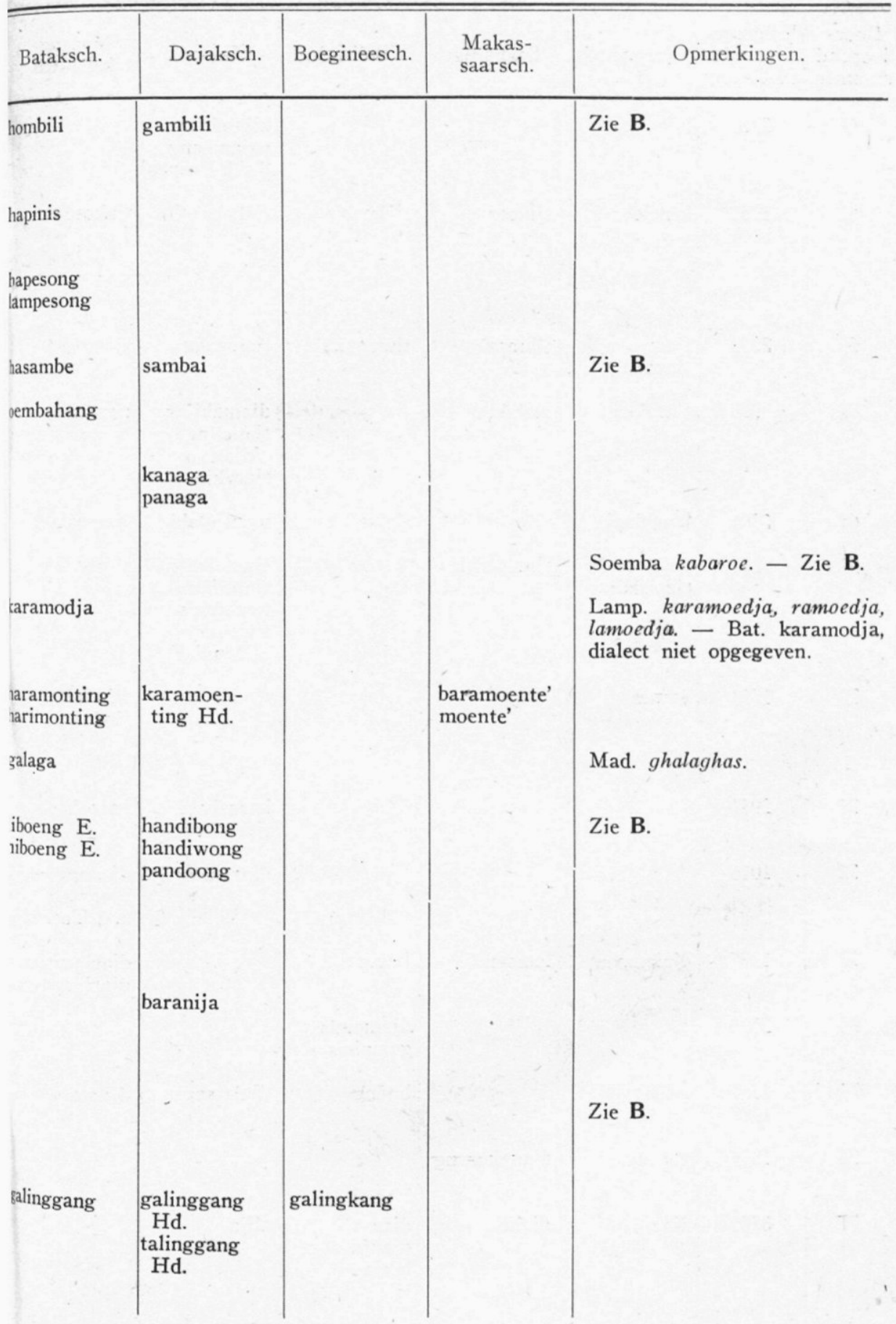


A

\begin{tabular}{|c|c|c|c|c|c|c|}
\hline $\begin{array}{l}\text { Door- } \\
\text { loopend } \\
\text { nummer. }\end{array}$ & $\mid \begin{array}{c}\text { Volgnum- } \\
\text { mer wb. } \\
\text { de Clercq. }\end{array}$ & Javaansch. & Soendaasch. & Baliesch. & Maleisch. & $\begin{array}{l}\text { Menang- } \\
\text { kabausch. }\end{array}$ \\
\hline 64 & 2751 & & & & $\begin{array}{l}\text { kijambang } \\
\text { pajambang } \\
\text { (W.k.Borneo) }\end{array}$ & \\
\hline 65 & 1951 & kěntjoer & tjikoer & tjĕkoeh & tjĕkoer & tjakoeĕ \\
\hline 66 & 2295 & $\begin{array}{l}\text { tjampaka } \\
\text { tjapaka }\end{array}$ & tjampaka & tjampaka & tjampaka & tjampaga \\
\hline 67 & 918 & tjaraken & malakian & & $\begin{array}{l}\text { djamakijan } \\
\text { tjama(ng)- } \\
\text { kijan } \\
\text { tjarakin }\end{array}$ & $\begin{array}{l}\text { simalakijan } \\
\text { tjoemalakijan }\end{array}$ \\
\hline 68 & 3301 & kamalagi & & tjalagi & mantjalaki & tjoemalagi \\
\hline 69 & 353 & $\begin{array}{l}\text { tjampědak } \\
\text { tjapědak }\end{array}$ & tjampědak & & $\begin{array}{l}\text { tjampědak } \\
\text { tjapédak } \\
\text { tambědak } \\
\text { tiwadak } \\
\text { (Bandjar) }\end{array}$ & tjoebadak \\
\hline 70 & 1573 & dawan & • & & tjandawan & $\begin{array}{l}\text { tjindawan } \\
\text { tindawan }\end{array}$ \\
\hline 71 & 2939 & & & & $\begin{array}{l}\text { karoeboet } \\
\text { tjaroeboet }\end{array}$ & karoeboeik \\
\hline 72 & 1016 & & & & djarěnang & $\begin{array}{l}\text { djanang } \\
\text { djarnang } \\
\text { v.d. Toorn }\end{array}$ \\
\hline 73 & 1277 & djalamoen & lamoen & lamoen & & $\begin{array}{l}\text { djari amboen } \\
\text { djari amoen }\end{array}$ \\
\hline 74 & 2226 & & . & $\begin{array}{l}\text { djampinis } \\
\text { gampinis }\end{array}$ & & \\
\hline 75 & $\begin{array}{l}1555 \\
1987\end{array}$ & latěng & & latěng & djalatang & djilatang \\
\hline 76 & 1835 & gorang & djangkorang & & & \\
\hline 77 & 3556 & djae & djahe & $\begin{array}{l}\text { djae } \\
\text { djahja } \\
\text { lahja }\end{array}$ & alija & \\
\hline
\end{tabular}




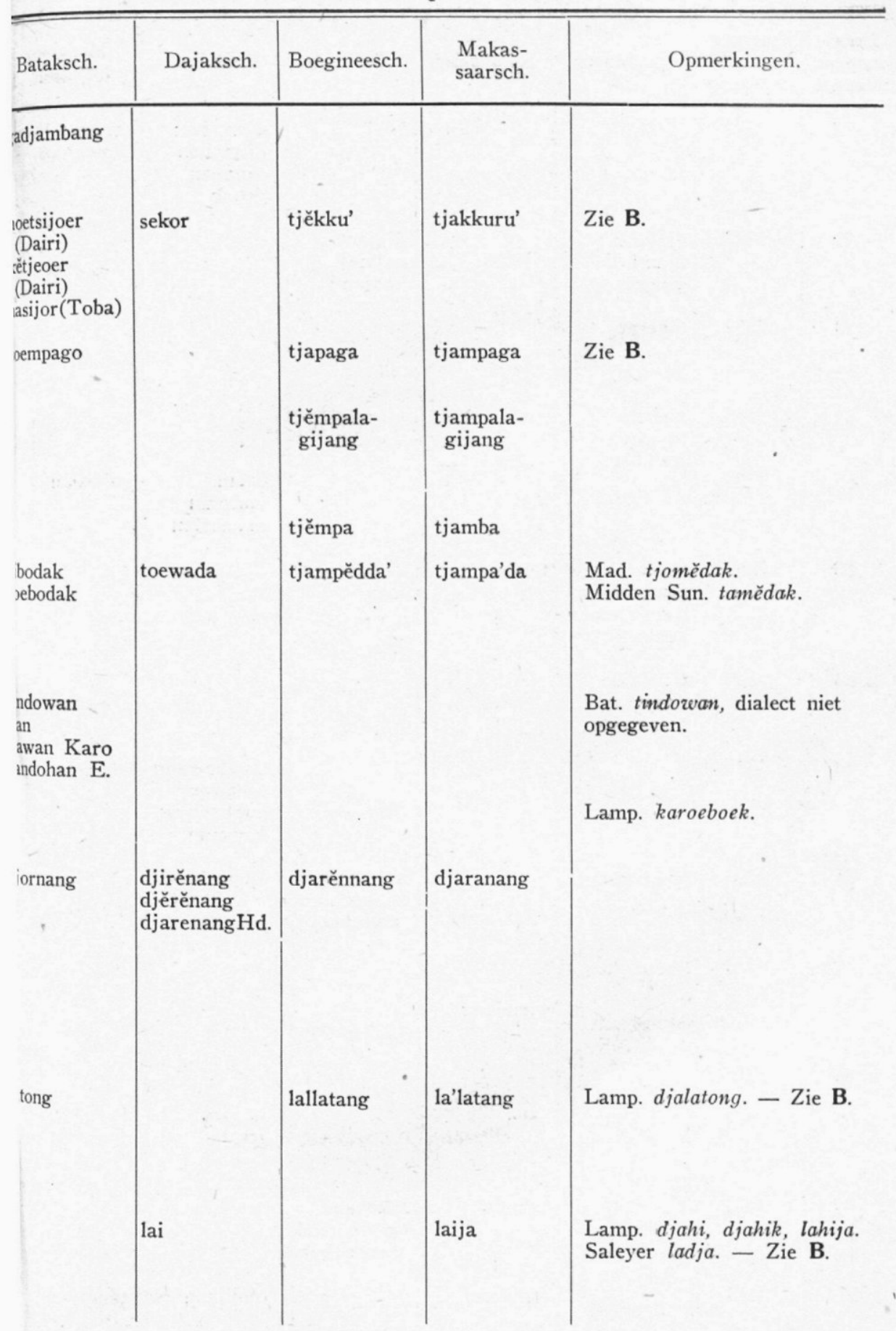


354 GELIJKHEID EN VERSCHIL VOORVOEGSELS IN INDONESISCHE TAI.EN.

A

\begin{tabular}{|c|c|c|c|c|c|c|}
\hline $\begin{array}{c}\text { Door- } \\
\text { loopend } \\
\text { nummer. }\end{array}$ & \begin{tabular}{|} 
Volgnum- \\
mer wb. \\
de Clercq.
\end{tabular} & Javaansch. & Soendaasch. & Baliesch. & Maleisch. & $\begin{array}{l}\text { Menang- } \\
\text { kabausch. }\end{array}$ \\
\hline 78 & 3513 & & & - & $\begin{array}{l}\text { djantahan } \\
\text { djintahan } \\
\text { djitahan } \\
\text { djitah }\end{array}$ & $\begin{array}{l}\text { gitan } \\
\text { langgitan }\end{array}$ \\
\hline 79 & 1887 & $\begin{array}{l}\text { djajanti } \\
\text { djanti } \\
\text { gijanti }\end{array}$ & & $\begin{array}{l}\text { djajanti } \\
\text { gajanti } \\
\text { kadjanti }\end{array}$ & djanti & \\
\hline 80 & 2319 & $\begin{array}{l}\text { tăgěrat } \\
\text { săgĕrat } \\
\text { kădĕrat }\end{array}$ & & . & 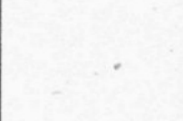 & - \\
\hline 81 & $\begin{array}{r}683 \\
.\end{array}$ & $\begin{array}{l}\text { ambalo } \\
\text { tambalo } \\
\text { trambalo }\end{array}$ & & & & \\
\hline & 1184 & 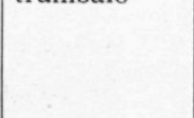 & & $i$ & $\begin{array}{l}\text { balau } \\
\text { ambalau } \\
\text { mambalau }\end{array}$ & ambalau \\
\hline 82 & 2860 & $\begin{array}{l}\text { tanggoeloen } \\
\text { tinggoeloen } \\
\text { tranggoeloen } \\
\text { goeloen }\end{array}$ & tanggoeloen & tranggoeloen & & \\
\hline 83 & 220 & $\begin{array}{l}\text { tanalajoe } \\
\text { tinalajoe } \\
\text { toenalajoe }\end{array}$ & & & & \\
\hline 84 & 1823 & & & & $\begin{array}{l}\text { tangkawang } \\
\text { takawang } \\
\text { angkawang } \\
\text { kawang }\end{array}$ & singkawang \\
\hline 85 & 2723 & koemoekoes & & $\begin{array}{l}\text { koemoekoes } \\
\text { tamboekoes } \\
\text { tamoekoes }\end{array}$ & kamoekoes & \\
\hline 86 & 532 & & & & & \\
\hline 87 & & & toerijang & & & \\
\hline 88 & 3313 & & & - & & \\
\hline 89 & 630 & & sěbe & & $\begin{array}{l}\text { tasěbih } \\
\text { sěbeh }\end{array}$ & \\
\hline 90 & 3166 & & takokak & $\begin{array}{l}\text { takokak } \\
\text { tjoengkokak } \\
\text { toeoengkokah }\end{array}$ & & \\
\hline 91 & 413 & - & tamijang & & tamijang & tamijang \\
\hline
\end{tabular}


GELIJKHEID EN VERSCHIL VOORVOEGSELS IN INDONESISCHE TALEN. 355

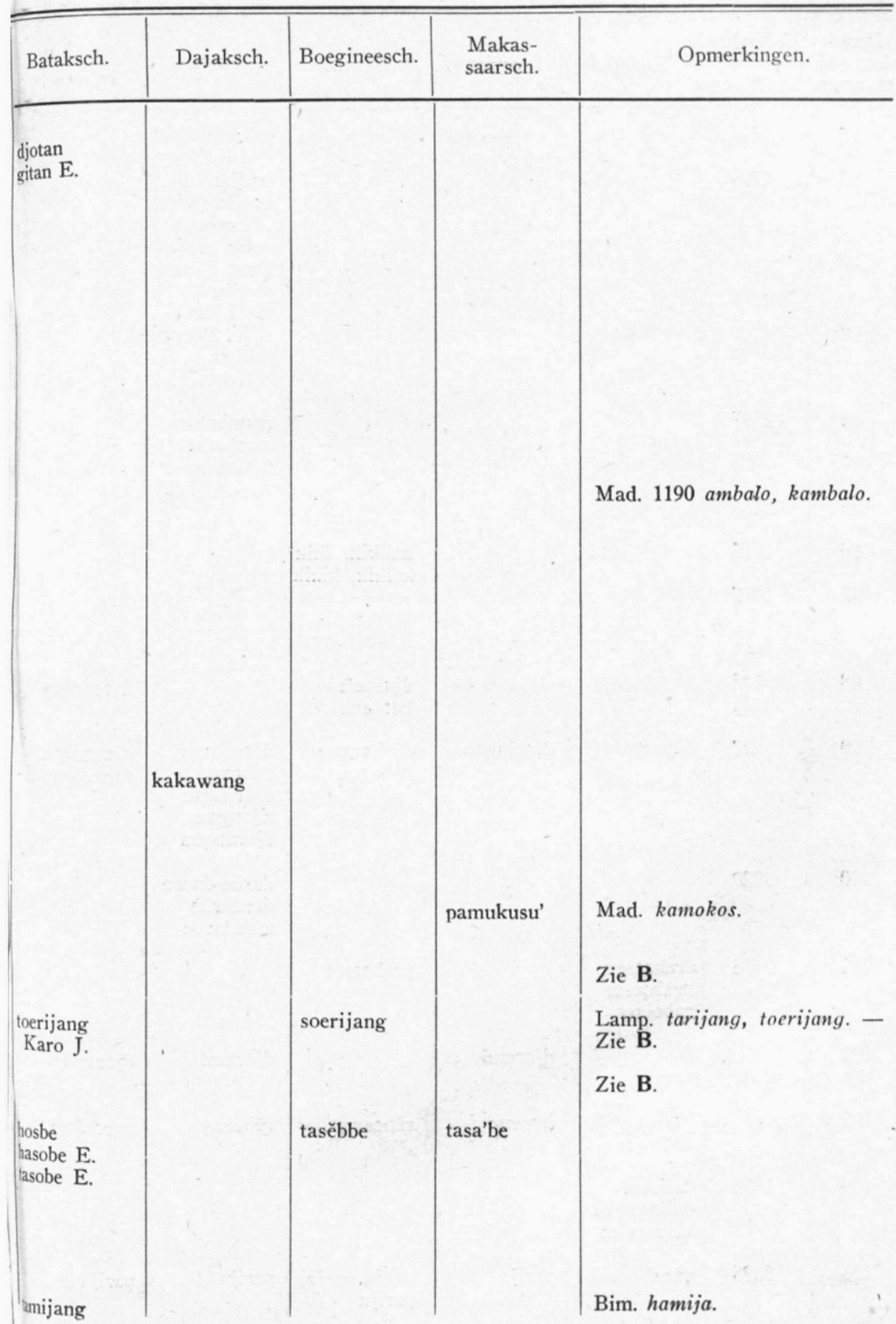


A

\begin{tabular}{|c|c|c|c|c|c|c|}
\hline $\begin{array}{l}\text { Door- } \\
\text { loopend } \\
\text { nummer. }\end{array}$ & $\begin{array}{l}\text { Volgnum- } \\
\text { mer wb. } \\
\text { de Clercq. }\end{array}$ & Javaansch. & Soendaasch. & Baliesch. & Maleisch. & $\begin{array}{l}\text { Menang- } \\
\text { kabausch. }\end{array}$ \\
\hline 92 & 1414 & & & & taboeta & \\
\hline 93 & 1396 & & & & $\begin{array}{l}\text { balijan } \\
\text { boelin (West } \\
\text { Borneo) } \\
\text { oelin (Zuid- } \\
\text { Oost Borneo) } \\
\text { onglin } \\
\text { tabalijan } \\
\text { (W. Borneo) } \\
\text { talijan } \\
\text { (Koetai) }\end{array}$ & \\
\hline 94 & 2597 & & & & $\begin{array}{l}\text { mambatoe } \\
\text { marbatoe } \\
\text { tambatoe }\end{array}$ & \\
\hline 95 & 3153 & & & & & \\
\hline 96 & 1755 & & & $\begin{array}{l}\text { kalikih, ikik } \\
\text { kaikik, kikik }\end{array}$ & & \\
\hline 97 & 1477 & & & & & \\
\hline 98 & $\begin{array}{l}138 \\
141\end{array}$ & & & $\begin{array}{l}\text { djasoe(n) } \\
\text { kasoena }\end{array}$ & & dasoen \\
\hline 99 & 22 & daringo & djaringao & $\begin{array}{l}\text { djahangoe } \\
\text { djangoe }\end{array}$ & $\begin{array}{l}\text { djarijango, } \\
\text { rangau, } \\
\text { djaringau } \\
\text { rijangau } \\
\text { djarangau }\end{array}$ & $\begin{array}{l}\text { djarangau } \\
\text { djarijangau }\end{array}$ \\
\hline 100 & 3029 & & & & $\begin{array}{l}\text { daroe-daroe } \\
\text { dardaroe } \\
\text { mandaroe }\end{array}$ & \\
\hline 101 & 2616 & $\begin{array}{l}\text { draboeset } \\
\text { praboeset } \\
\text { raboeset }\end{array}$ & & praboeset & . & \\
\hline 102 & & $\begin{array}{l}\text { dami } \\
\text { damẹn }\end{array}$ & djarami & & djarami & djarami \\
\hline 103 & & $\begin{array}{l}\text { boeng } \\
\text { ěboeng }\end{array}$ & iwoeng & rĕboeng & rĕboeng & raboeăng \\
\hline 104 & 1816 & $\begin{array}{l}\text { dalisěm } \\
\text { dalingsěm } \\
\text { kalingsěm }\end{array}$ & & & & \\
\hline 105 & 2336 & pare & parija & $\begin{array}{l}\text { pahja, paja, } \\
\text { parija }\end{array}$ & parija & parija \\
\hline
\end{tabular}




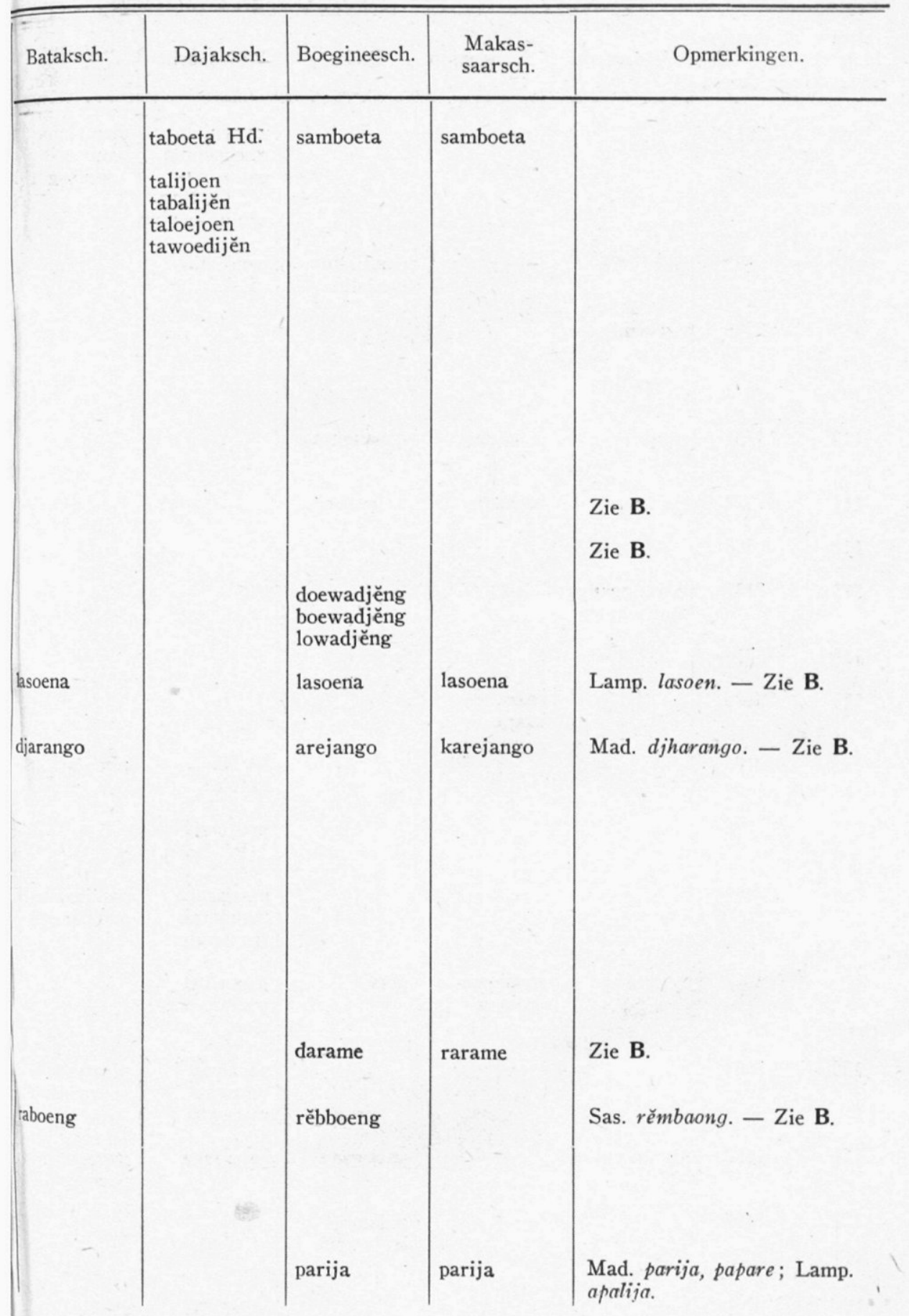


358 GELIJKHEIE EN VERSCHIL VOORVOEGSELS IN INDONESISCHE TALFN.

A

\begin{tabular}{|c|c|c|c|c|c|c|}
\hline $\begin{array}{l}\text { Door- } \\
\text { loopend } \\
\text { nummer. }\end{array}$ & $\begin{array}{l}\text { Volgnum- } \\
\text { mer wb. } \\
\text { de Clercq. }\end{array}$ & Javaansch. & Soendaasch. & Baliesch. & Maleisch. & $\begin{array}{l}\text { Menang- } \\
\text { kabausch. }\end{array}$ \\
\hline 106 & 2911 & & & & $\begin{array}{l}\text { ampěning } \\
\text { mampěning } \\
\text { pampaning } \\
\text { (Z.O. Born.) } \\
\text { pěning-pěning }\end{array}$ & $\begin{array}{l}\text { mampining } \\
\text { paniěng- } \\
\text { paniěng }\end{array}$ \\
\hline 107 & 539 & pandjalin & & $\begin{array}{l}\text { pandjalin } \\
\text { panjalin }\end{array}$ & $\begin{array}{l}\text { pandjalin } \\
\text { Pal. }\end{array}$ & \\
\hline 108 & 2295 & $\begin{array}{l}\text { patjari } \\
\text { lotjari }\end{array}$ & & & & \\
\hline 109 & 2034 & & & & & \\
\hline 110 & 1781 & panggang & panggang & papanggang & & \\
\hline 111 & 827 & papasan & papasan & paspasan & & \\
\hline 112 & 568 & & & & & \\
\hline 113 & 2131 & $\begin{array}{l}\text { parengpeng } \\
\text { marengpeng }\end{array}$ & & & & \\
\hline 114 & 710 & & & & & \\
\hline 115 & 2626 & & $\begin{array}{l}\text { pasra } \\
\text { kasra }\end{array}$ & & & \\
\hline 116 & 2106 & . & & & $\begin{array}{l}\text { patola } \\
\text { katola }\end{array}$ & pitoela \\
\hline 117 & 720 & & . & & $\begin{array}{l}\text { padjatei } \\
\text { (W.-Born.) }\end{array}$ & \\
\hline 118 & 2401 & & $2-$ & & $\begin{array}{l}\text { pandarah } \\
\text { mandarah } \\
\text { tjindarah }\end{array}$ & $\begin{array}{l}\text { pandarahan } \\
\text { mandarahian }\end{array}$ \\
\hline 119 & 3417 & & $\begin{array}{l}\text { poengpoe- } \\
\text { roetan }\end{array}$ & poelět & $\begin{array}{l}\text { papoeloet } \\
\text { poeloet-poe- } \\
\text { loet }\end{array}$ & \\
\hline 120 & 2058 & & & & $\begin{array}{l}\text { parawas } \\
\text { pirawas } \\
\text { marawas }\end{array}$ & $\begin{array}{l}\text { piraweh } \\
\text { poeraweh }\end{array}$ \\
\hline 121 & 1852 & gagan-gagan & - & panggaga & panggaga & $\begin{array}{l}\text { pagaga } \\
\text { poegaga }\end{array}$ \\
\hline 122 & 407 & & & $\begin{array}{l}\text { pidampĕl } \\
\text { kadampěl }\end{array}$ & & \\
\hline
\end{tabular}




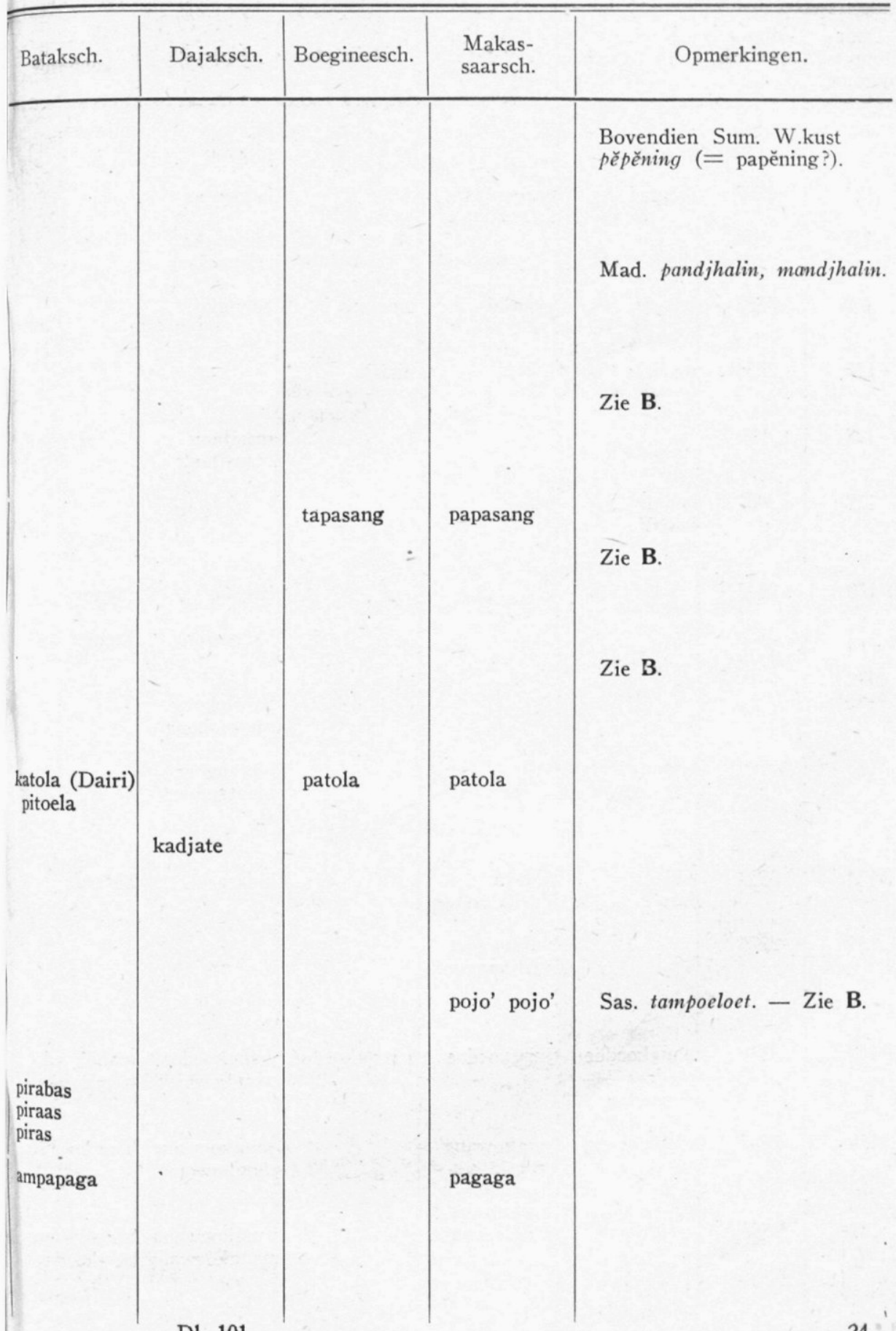

D1. 101. 
A

\begin{tabular}{|c|c|c|c|c|c|c|}
\hline $\begin{array}{l}\text { Door- } \\
\text { loopend } \\
\text { nummer. }\end{array}$ & $\begin{array}{l}\text { Volgnum- } \\
\text { mer wb. } \\
\text { de Clercq. }\end{array}$ & Javaansch. & Soendaasch. & Baliesch. & Maleisch. & $\begin{array}{l}\text { Menang- } \\
\text { kabausch. }\end{array}$ \\
\hline 123 & 2862 & 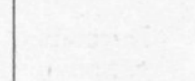 & & & $\begin{array}{l}\text { bijawas } \\
\text { pijawas }\end{array}$ & pijaweh \\
\hline 124 & 2783 & loentas & baroentas & & baloentas & \\
\hline 125 & 934 & & & & $\begin{array}{l}\text { biloengka } \\
\text { (Bandjar) }\end{array}$ & \\
\hline 126 & 3557 & bangle & panglaj & woengli & boenglai & \\
\hline 127 & 2736 & maritja & & maitja & & \\
\hline 128 & 990 & & & & $\begin{array}{l}\text { masijang } \\
\text { mansijang }\end{array}$ & mansijang \\
\hline 129 & 2937 & $\begin{array}{l}\text { badụali } \\
\text { kad̦ali } \\
\text { dali }\end{array}$ & padali & & & \\
\hline 130 & 3543 & & & & bagaoe & bigaoe \\
\hline 131 & $\begin{array}{l}2478 \\
2479\end{array}$ & & & & banoewang & binoewang \\
\hline 132 & 51 & & & & $\begin{array}{l}\text { barombong } \\
\text { marombong }\end{array}$ & \\
\hline 133 & $\begin{array}{l}580 \\
582 \\
583 \\
584\end{array}$ & bintangoer & & & $\begin{array}{l}\text { bintangoer } \\
\text { mantangoer }\end{array}$ & \\
\hline 134 & 3559 & $\begin{array}{l}\text { widara } \\
\text { dara }\end{array}$ & $\begin{array}{l}\text { widara } \\
\text { bidara }\end{array}$ & & bidara & bidara \\
\hline 135 & 2276 & & $\begin{array}{l}\text { bidjanggoet } \\
\text { poedjanggoet }\end{array}$ & & & \\
\hline 136 & & & & & & \\
\hline 137 & $\begin{array}{l}2340 \\
2343\end{array}$ & $\begin{array}{l}\text { mangkoeḍoe } \\
\text { koeḍoe } \\
\text { kěmoeḍoe }\end{array}$ & jangkoedoe & woengkoedce & $\begin{array}{l}\text { mangkoedoe } \\
\text { bangkoedoe }\end{array}$ & $\begin{array}{l}\text { mangkoedoe } \\
\text { bingkoedoe }\end{array}$ \\
\hline 138 & 2532 & bangkowang & pangkowang & & $\begin{array}{l}\text { sangkoewang } \\
\text { sangkowang. }\end{array}$ & bangkoewang \\
\hline 139 & 2558 & & jangkoewang & . & $\begin{array}{l}\text { bangkoewang } \\
\text { mangkoewang }\end{array}$ & $\begin{array}{l}\text { bangkoewang } \\
\text { bingkoewang } \\
\text { Wb. }\end{array}$ \\
\hline
\end{tabular}


GELIJKHEID EN VERSCHIL VOORVOEGSELS IN INDONESISCHE TALEN. 361

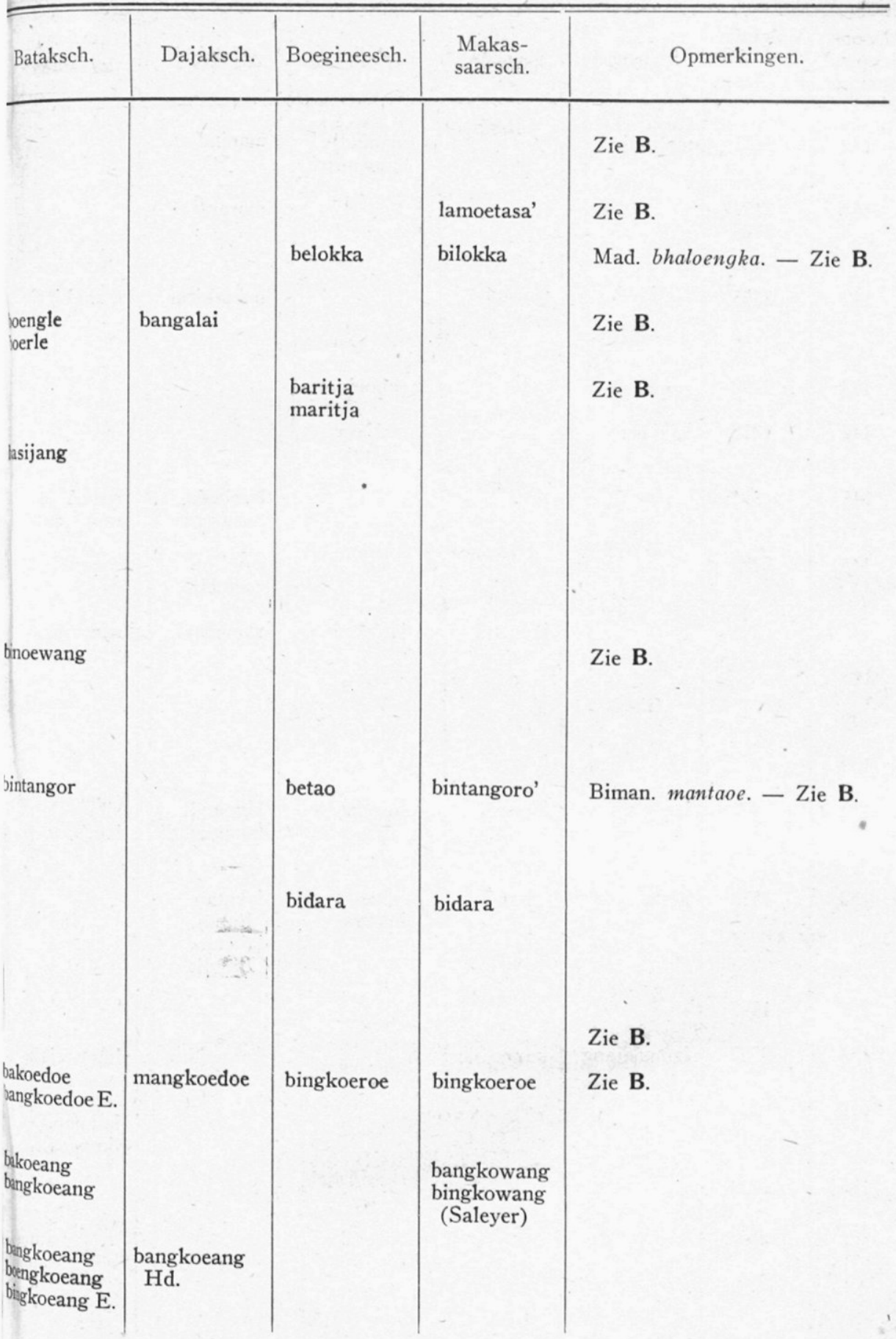


A

\begin{tabular}{|c|c|c|c|c|c|c|}
\hline $\begin{array}{c}\text { Door- } \\
\text { loopend } \\
\text { nummer. }\end{array}$ & $\begin{array}{c}\text { Volgnum- } \\
\text { mer wb. } \\
\text { de Clercq. }\end{array}$ & Javaansch. & Soendaasch. & Baliesch. & Maleisch. & $\begin{array}{l}\text { Menang- } \\
\text { kabausch. }\end{array}$ \\
\hline 140 & 1671 & malindjo & & $\begin{array}{l}\text { manindjo } \\
\text { manendjo }\end{array}$ & $\begin{array}{l}\text { manindjau } \\
\text { v. R. }\end{array}$ & \\
\hline 141 & $\begin{array}{l}3124 \\
3125\end{array}$ & & & & maranti & \\
\hline 142 & 3355 & & koeraj & & mangkirai & mangkirai \\
\hline 143 & 2299 & ramboejoet & & raboejoet & & \\
\hline 144 & 1218 & radjasa & & $\begin{array}{l}\text { radjasa } \\
\text { ridjasa }\end{array}$ & & \\
\hline 145 & 591 & & & . & $\begin{array}{l}\text { lambega } \\
\text { rambega }\end{array}$ & $\begin{array}{l}\text { roembiga } \\
\text { rambega }\end{array}$ \\
\hline 146 & 2289 & & & & $\begin{array}{l}\text { rambija } \\
\text { roembija }\end{array}$ & roembija \\
\hline 147 & 296 & & lampani & lampěni & rampěnai & rampanai \\
\hline 148 & & & & & & \\
\hline 149 & & & & & & \\
\hline 150 & . & & & & & \\
\hline 151 & 3473 & lagoendi & lagondi & liligondi & $\begin{array}{l}\text { lagoendi } \\
\text { langgoendi }\end{array}$ & $\begin{array}{l}\text { silagoendi } \\
\text { langgoendi }\end{array}$ \\
\hline 152 & $\begin{array}{r}2513 \\
0.27\end{array}$ & kětan & kětan & $\begin{array}{l}\text { kĕtan } \\
\text { lakětan }\end{array}$ & $\begin{array}{r}\text { lakatan } \\
\text { Bandj. } \\
\text { lakětan } \\
\text { Bandj. }\end{array}$ & \\
\hline 153 & 1897 & & & & & \\
\hline 154 & 3552 & lampoejang & lampoejang & & lampojang & lampoejang \\
\hline 155 & 351 & & & & & $\begin{array}{l}\text { lampata } \\
\text { limpata }\end{array}$ \\
\hline 156 & 704 & & & & & \\
\hline 157 & 464 & & & & & \\
\hline
\end{tabular}




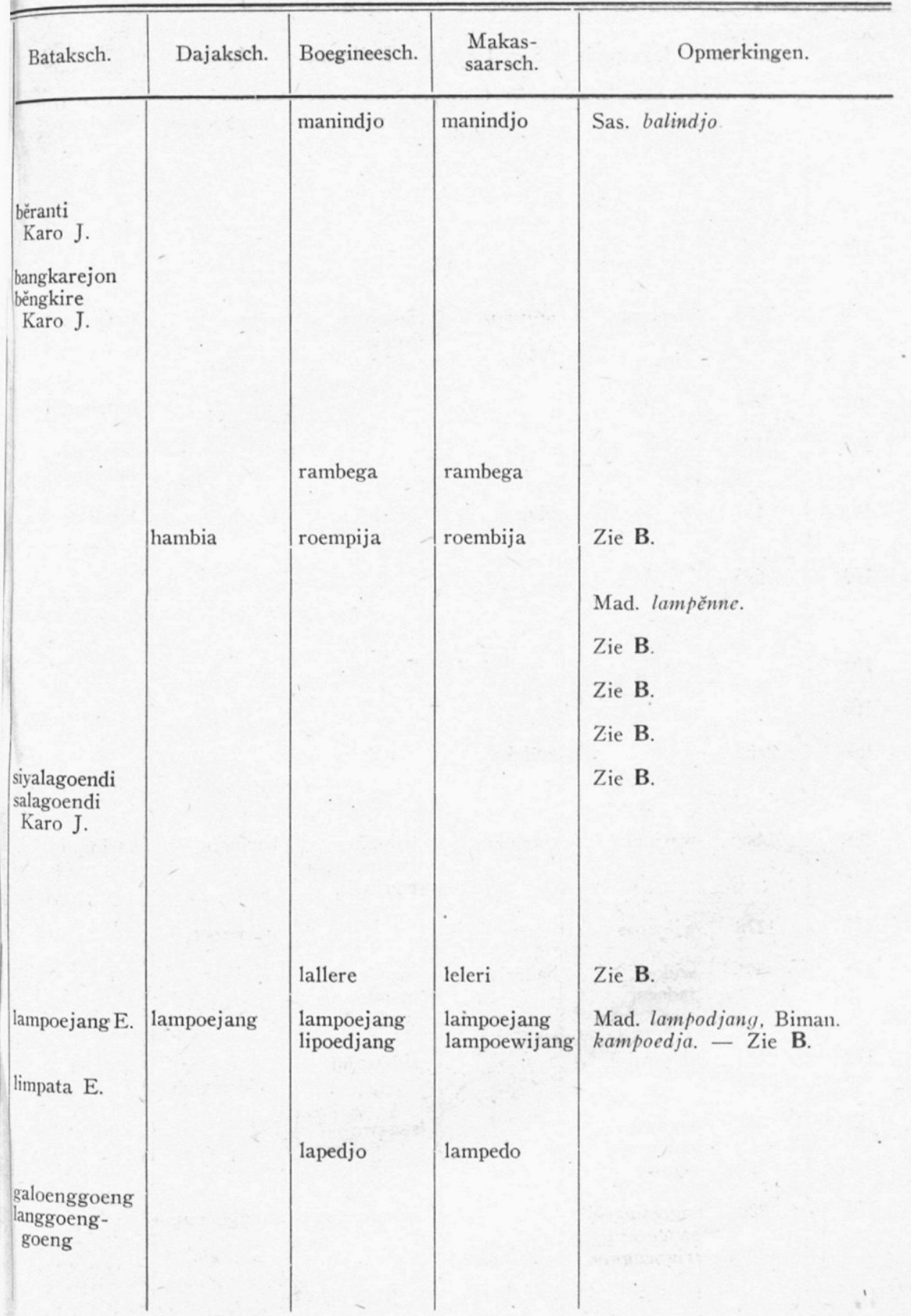


A

\begin{tabular}{|c|c|c|c|c|c|c|}
\hline $\begin{array}{c}\text { Door- } \\
\text { loopend } \\
\text { nummer. }\end{array}$ & $\begin{array}{l}\text { Volgnum- } \\
\text { mer wb. } \\
\text { de Clercq. }\end{array}$ & Javaansch. & Soendaasch. & Baliesch. & Maleisch. & $\begin{array}{l}\text { Menang- } \\
\text { kabausch. }\end{array}$ \\
\hline 158 & 159 & laos & & lahwas & langkoewas & langkoeweh \\
\hline 159 & & & & & - & \\
\hline 160 & 2883 & $\begin{array}{l}\text { angsana } \\
\text { asana } \\
\text { sana }\end{array}$ & angsana & $\begin{array}{l}\text { angsana } \\
\text { asana }\end{array}$ & sěna & langsana \\
\hline 161 & 974 & & & & & lintaboeăng \\
\hline 162 & 3174 & & & & & $\begin{array}{l}\text { latojoeng } \\
\text { lantojoeng }\end{array}$ \\
\hline 163 & 151 & & biha & bijah & birah & birah \\
\hline 164 & 695 & & & & & \\
\hline 165 & & & & $-\cdots$ & & \\
\hline 166 & & · & & & & \\
\hline $\begin{array}{l}167 \\
168\end{array}$ & 2822 & & kadaka & wandaka & & \\
\hline 169 & 1442 & waringin & tjaringin & $\begin{array}{l}\text { baingin } \\
\text { [w] oeringen } \\
\text { waringin }\end{array}$ & baringin & baringin \\
\hline 170 & 1278 & wiloeroe & & & paloeroen & \\
\hline 171 & 591 & $\begin{array}{l}\text { widoeri } \\
\text { sadoeri }\end{array}$ & badori & $\begin{array}{l}\text { mandoeri } \\
\text { mandori } \\
\text { wadoeri }\end{array}$ & & \\
\hline 172 & $\begin{array}{l}2452 \\
3518\end{array}$ & $\begin{array}{c}\text { sidawajah } \\
"\end{array}$ & & $\begin{array}{c}\text { sidawajah } \\
"\end{array}$ & sadoewajah & \\
\hline 173 & 41 & $\begin{array}{l}\text { sagawe } \\
\text { sanggawe } \\
\text { sigawe }\end{array}$ & & sagawe & & \\
\hline 174 & 820 & $\begin{array}{l}\text { sagoenggoe } \\
\text { sanggoenggoe } \\
\text { rrigoenggoe }\end{array}$ & & singgoenggoe & sanggoenggoe & \\
\hline
\end{tabular}


GELIJKHEID EN VERSCHIL VOORVOEGSELS IN INDONESISCHE TALEN. 365

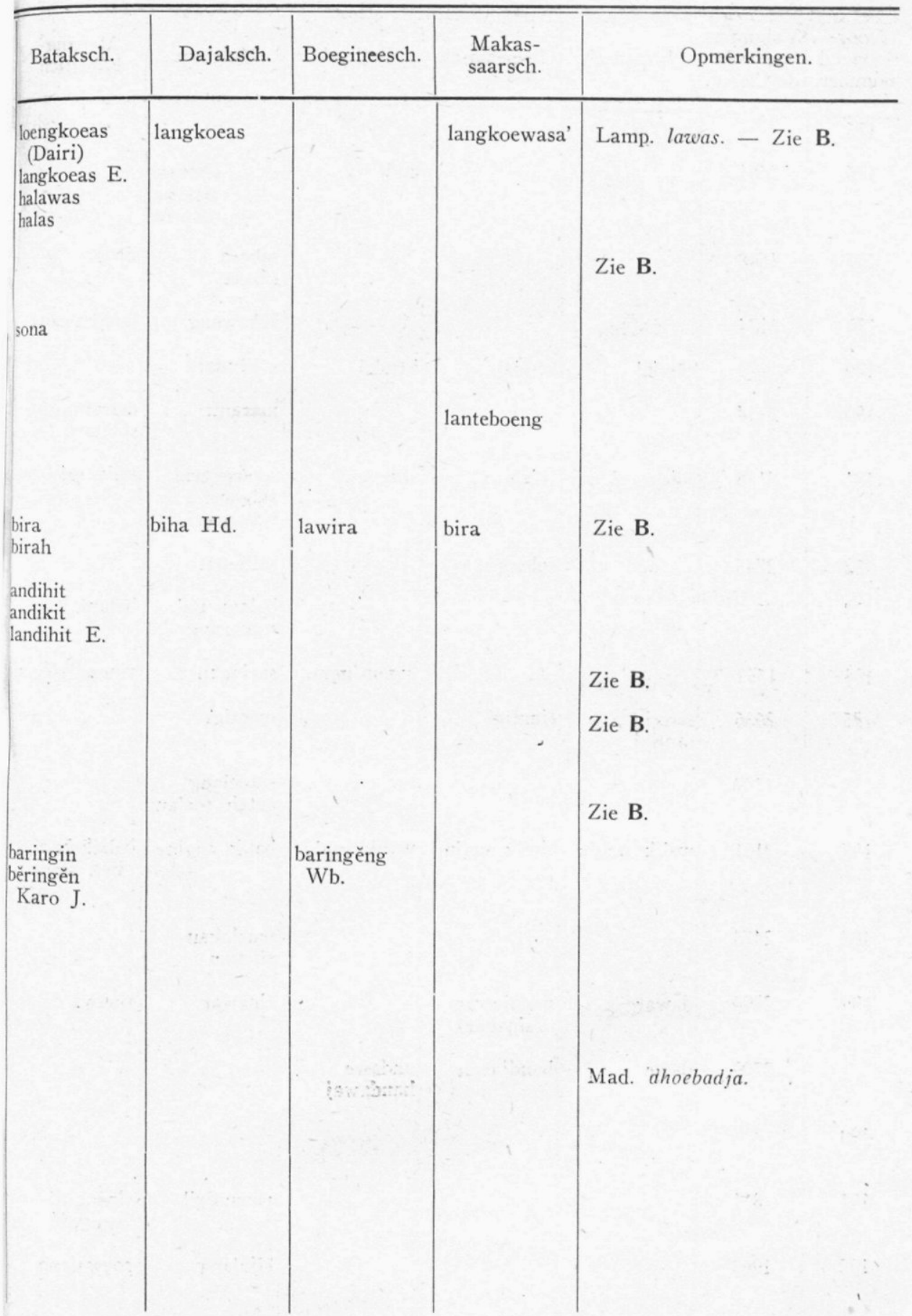


A

\begin{tabular}{|c|c|c|c|c|c|c|}
\hline $\begin{array}{c}\text { Door- } \\
\text { loopend } \\
\text { nummer. }\end{array}$ & $\begin{array}{l}\text { Volgnum- } \\
\text { mer wb. } \\
\text { de Clercq. }\end{array}$ & Javaansch. & Soendaasch. & Baliesch. & Maleisch. & $\begin{array}{l}\text { Menang- } \\
\text { kabausch. }\end{array}$ \\
\hline \multicolumn{7}{|l|}{175} \\
\hline 176 & 2661 & & & atak & & \\
\hline 177 & 1648 & & & & $\begin{array}{l}\text { sabasa } \\
\text { sibasa }\end{array}$ & sibasa \\
\hline 178 & 3124 & & & & sakawang & sangkawang \\
\hline 179 & 879 & kĕṇḍal & kěndal & kěndal & sakěndal & \\
\hline 180 & 3114 & & & & maranti & $\begin{array}{l}\text { maranti } \\
\text { soeranti }\end{array}$ \\
\hline 181 & 3138 & siḍagoeri & sidagori & siligoewi & $\begin{array}{l}\text { soelagoerai } \\
\text { salgoeri } \\
\text { tjalagoeri }\end{array}$ & saligoeri \\
\hline 182 & 2745 & $f^{\prime}$ & solempat & & salimpat & \\
\hline 183 & 2625 & & & & $\begin{array}{l}\text { balam Pal. } \\
\text { samaram }\end{array}$ & balam \\
\hline 184 & 1552 & & & ingan-ingan & saringan & ringan-ringan \\
\hline 185 & 2636 & $\begin{array}{l}\text { satigi } \\
\text { santigi }\end{array}$ & tjantigi & & mantigi & \\
\hline 186 & 1389 & & & toelang & $\begin{array}{l}\text { satoelang } \\
\text { patah toelang }\end{array}$ & \\
\hline 187 & 2151 & walik angin & tjalik angin & walik angin & balik angin & $\begin{array}{l}\text { baliěk-ba- } \\
\text { liěk angin }\end{array}$ \\
\hline 188 & 2473 & & & & $\begin{array}{l}\text { marlokan } \\
\text { silokan }\end{array}$ & \\
\hline \multirow[t]{2}{*}{189} & 2894 & dawar & $\begin{array}{c}\text { pandjawar } \\
\text { (sinagar) }\end{array}$ & . & sinawar & sinawa \\
\hline & 2709 & dawe & handjawar & $\begin{array}{l}\text { andawe } \\
\text { handawaj }\end{array}$ & & \\
\hline 190 & 838 & & r & & & \\
\hline 191 & 811 & & & & papanggil & $\begin{array}{l}\text { sipanggiě- } \\
\text { panggiě }\end{array}$ \\
\hline 192 & 1963 & & & & sijalang & soewalang \\
\hline
\end{tabular}


GELIJKHEID EN VERSCHIL VOORVOEGSELS IN INDONESISCHE TALEN. 367

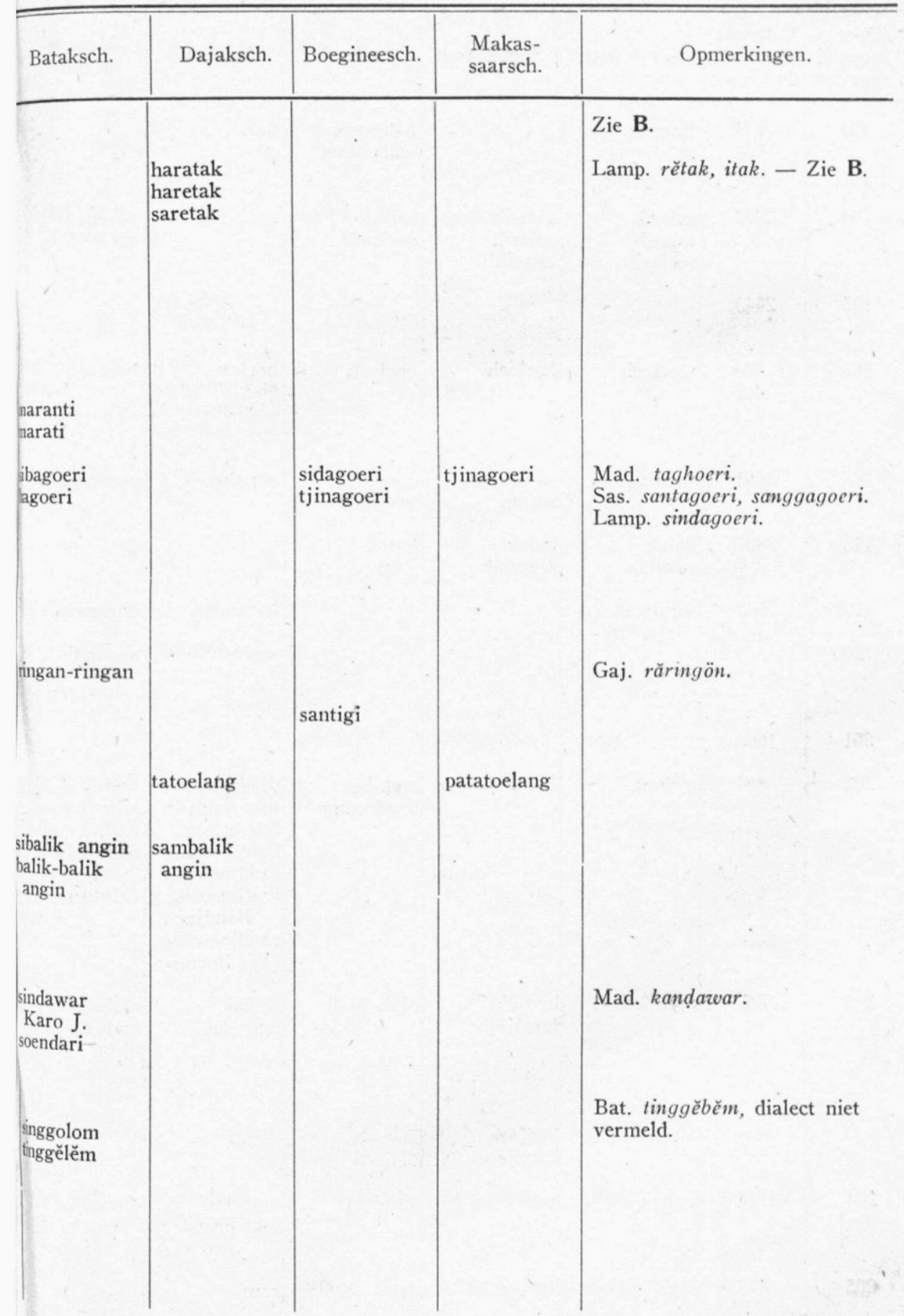


A

\begin{tabular}{|c|c|c|c|c|c|c|}
\hline $\begin{array}{c}\text { Door- } \\
\text { loopend } \\
\text { nummer. }\end{array}$ & $\begin{array}{l}\text { Volgnum- } \\
\text { mer wb. } \\
\text { de Clercq. }\end{array}$ & Javaansch. & Soendaasch. & Baliesch. & Maleisch. & $\begin{array}{l}\text { Menang- } \\
\text { kabausch. }\end{array}$ \\
\hline 193 & 541 & $\begin{array}{l}\text { latoeng } \\
\text { salatoeng } \\
\text { walatoeng }\end{array}$ & & $\begin{array}{l}\text { balatoeng } \\
\text { walatoeng }\end{array}$ & balatoeng & \\
\hline 194 & 2474 & $\begin{array}{l}\text { salasih } \\
\text { talasih } \\
\text { toelasih }\end{array}$ & $\begin{array}{l}\text { salasih } \\
\text { solasih } \\
\text { talasih }\end{array}$ & $\begin{array}{l}\text { salasib } \\
\text { soelasih }\end{array}$ & salasih & $\begin{array}{l}\text { soelasi } \\
\text { soelasiëh }\end{array}$ \\
\hline 195 & 2443 & & & & & \\
\hline 196 & $\begin{array}{l}404 \\
407 \\
413\end{array}$ & woeloeh & boeloeh & boeloeh & boeloh & boeloeëh \\
\hline 197 & 3501 & saroeni & $\begin{array}{l}\text { saroeni } \\
\text { saroni }\end{array}$ & $\begin{array}{l}\text { saroeni } \\
\text { saroni }\end{array}$ & saroenai & saroenai \\
\hline 198 & 2801 & $\begin{array}{l}\text { kalak } \\
\text { sakalak }\end{array}$ & $\begin{array}{l}\text { kalak } \\
\text { toeralak }\end{array}$ & kalak & & \\
\hline 199 & 693 & sarangan & & & & \\
\hline 200 & 563 & & & & samamboe & simamboe \\
\hline 201 & 1666 & & & & & \\
\hline 202 & 884 & andong & handjoewang & $\begin{array}{l}\text { andong } \\
\text { handroang }\end{array}$ & $\begin{array}{l}\text { djadjoewang } \\
\text { djoewang- } \\
\text { djoewang } \\
\text { landjoewang } \\
\text { sandjoewang } \\
\text { lindjoewang } \\
\text { Bandjar } \\
\text { randjoewang } \\
\text { (W. Borneo) }\end{array}$ & $\begin{array}{l}\text { lindjoewang } \\
\text { silindjoewant } \\
\text { andjiloewang } \\
\text { pandjaloe- } \\
\text { wang } \\
\text { (Midden } \\
\text { Sum.) }\end{array}$ \\
\hline 203 & 836 & djali & $\begin{array}{l}\text { hadjere } \\
\text { handjere }\end{array}$ & djali-djali & $\begin{array}{l}\text { djělai } \\
\text { andjĕlai }\end{array}$ & $\begin{array}{l}\text { andjalai } \\
\text { andjolai } \\
\text { djilai (Midd. } \\
\text { Sumatra) } \\
\text { indjilai (M. } \\
\text { Sumatra) }\end{array}$ \\
\hline 21)4 & 1514 & rampělas & hampělas & ampělas & $\begin{array}{l}\text { ampělas } \\
\text { mampělas }\end{array}$ & ampaleh \\
\hline 205 & 475 & rami & haramaj & dami & rami & \\
\hline
\end{tabular}




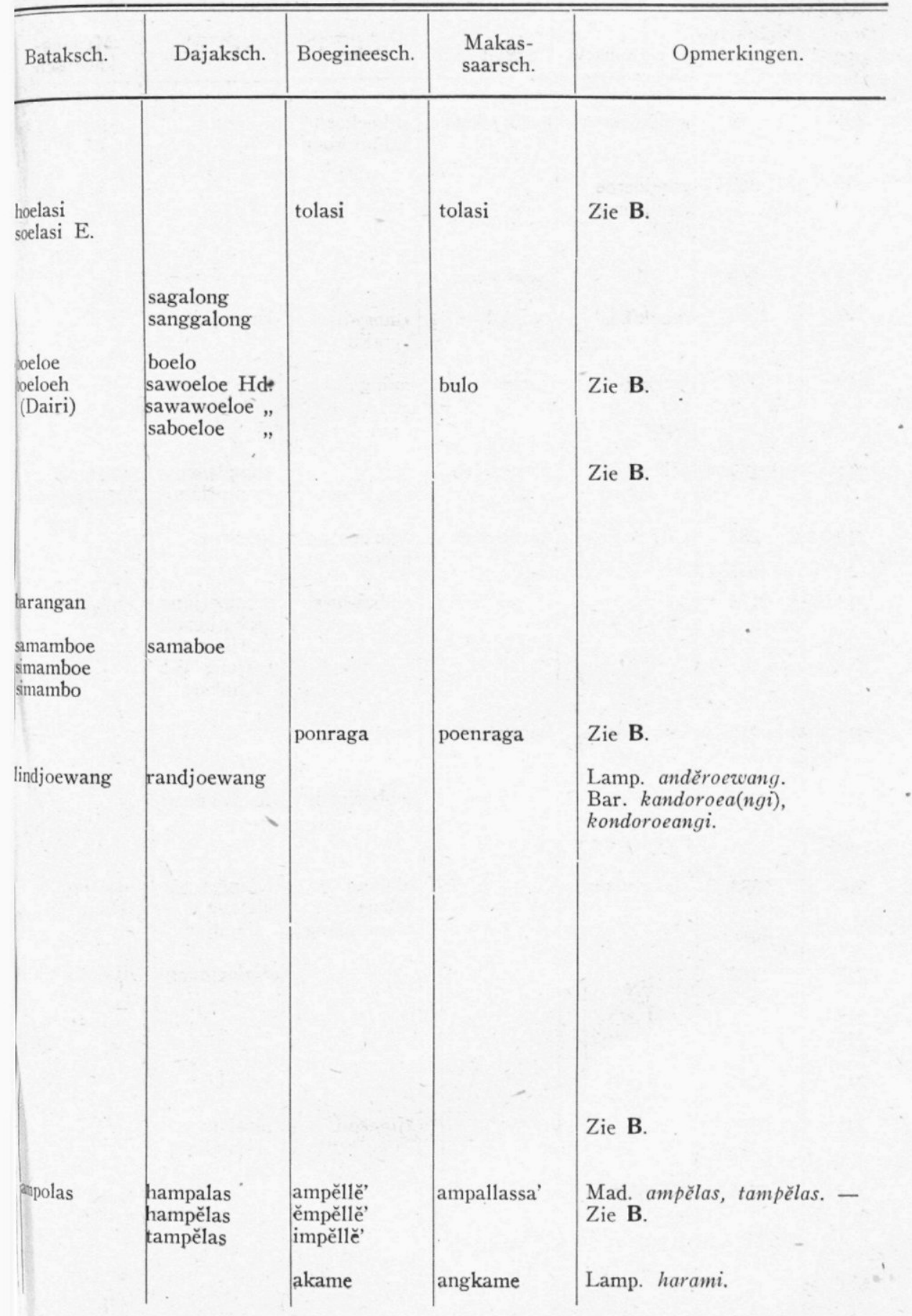




\begin{tabular}{|c|c|c|c|c|c|c|}
\hline $\begin{array}{l}\text { Door- } \\
\text { loopend } \\
\text { nummer. }\end{array}$ & $\begin{array}{l}\text { Volgnum- } \\
\text { mer wb. } \\
\text { de Clercq. }\end{array}$ & Javaansch. & Soendaasch. & Baliesch. & Maleisch. & $\begin{array}{l}\text { Menang- } \\
\text { kabausch. }\end{array}$ \\
\hline 206 & 36 & walikoekoen & harikoekoen & $\begin{array}{l}\text { alikoekoen } \\
\text { kalikoekoen }\end{array}$ & & \\
\hline 207 & 669 & $\begin{array}{l}\text { gandọdoeroe } \\
\text { kandoeroe } \\
\text { Wb́. }\end{array}$ & & - & & \\
\hline 208 & 878 & & & & & \\
\hline 209 & 1669 & tangkil & tangkil & $\begin{array}{l}\text { atangkil } \\
\text { tangkil }\end{array}$ & katangkil & \\
\hline 210 & 690 & $\begin{array}{l}\text { waringinan } \\
\text { nginging } \\
\text { ihing }\end{array}$ & $\begin{array}{l}\text { haringin } \\
\text { ringin }\end{array}$ & miing & 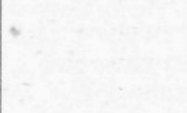 & \\
\hline 211 & 2169 & pělěm & $\begin{array}{l}\text { mangpělěm } \\
\text { Wb. }\end{array}$ & $\begin{array}{l}\text { pělěm } \\
\text { ampělěm }\end{array}$ & $\begin{array}{l}\text { ampělam } \\
\text { mampělam }\end{array}$ & $\begin{array}{l}\text { ampalam } \\
\text { marapalam }\end{array}$ \\
\hline 212 & 283 & garoe & garoe & $\begin{array}{l}\text { agaroe } \\
\text { garoe }\end{array}$ & gaharoe & \\
\hline 213 & 2175 & & & ambawang & $\begin{array}{l}\text { mambatjang } \\
\text { ambatjang } \\
\text { matjang } \\
\text { batjang Wb. } \\
\text { Klinkert }\end{array}$ & ambatjang \\
\hline 214 & 217 & bratawali & baratawali & antawali & & \\
\hline 215 & 2289 & $\begin{array}{l}\text { boeloeng } \\
\text { ramboeloeng } \\
\text { tramboeloen }\end{array}$ & & amboeloeng & 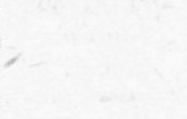 & \\
\hline 216 & 1883 & alang-alang & & $\begin{array}{l}\text { alalang } \\
\text { lalang } \\
\text { alang-alang }\end{array}$ & $\begin{array}{l}\text { lalang } \\
\text { alalang } \\
\text { Bandjar }\end{array}$ & $\begin{array}{l}\text { alalang } \\
\text { ilalang }\end{array}$ \\
\hline $\begin{array}{l}217 \\
218- \\
239\end{array}$ & 1182 & & & & djaloetoeng & djalotoeng \\
\hline 240 & 3545 & & $\therefore$ & & kaloebi & \\
\hline 241 & 3556 & & & tjipakan & $\begin{array}{l}\text { pipakan } \\
\text { (Bandjar) }\end{array}$ & \\
\hline 242 & 3366 & baloedroe & & & . & \\
\hline
\end{tabular}




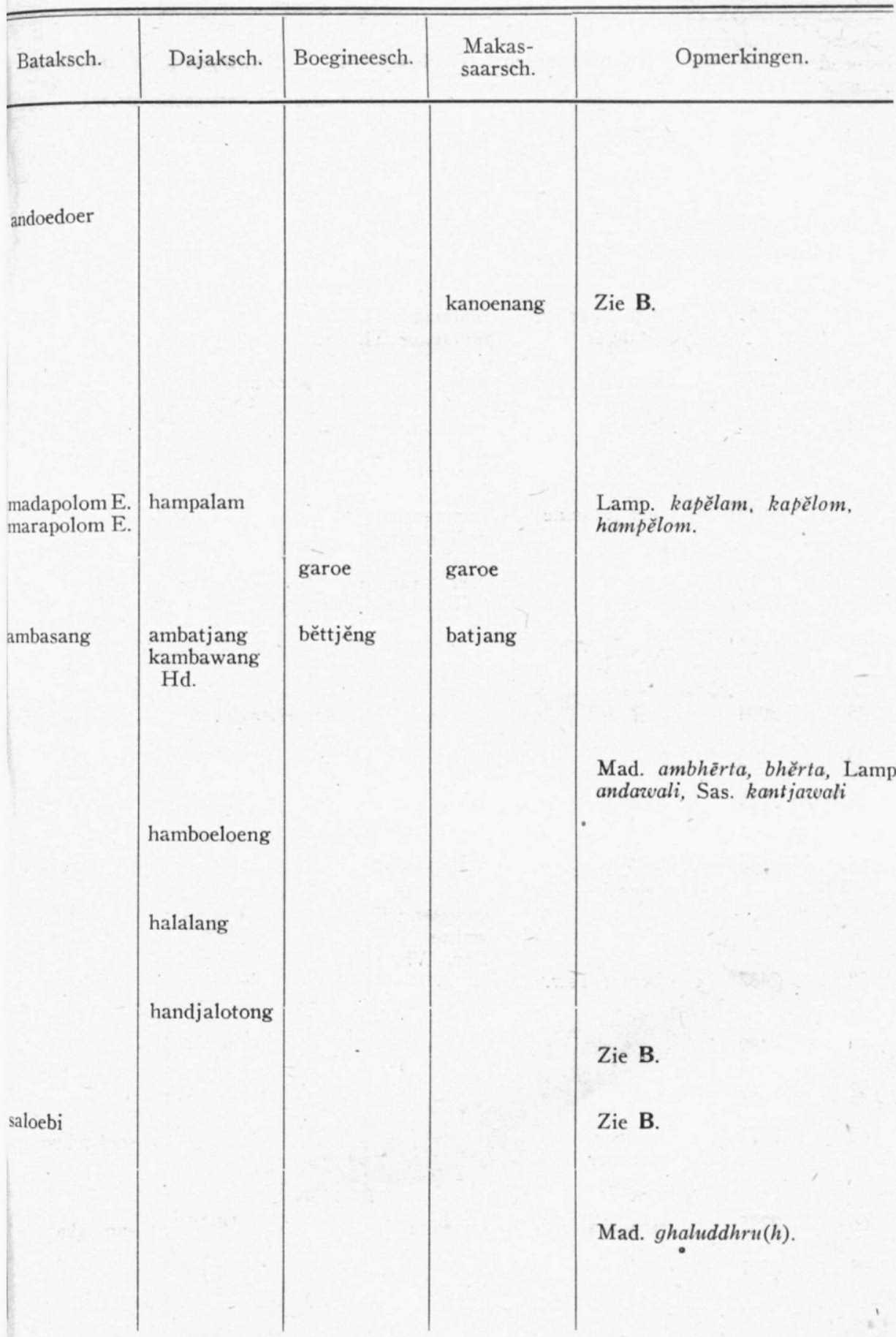


B

\begin{tabular}{|c|c|c|c|c|c|}
\hline $\begin{array}{l}\text { Door- } \\
\text { loopend } \\
\text { nummer. }\end{array}$ & $\begin{array}{l}\text { Volgnum- } \\
\text { mer wb. } \\
\text { de Clercq. }\end{array}$ & Tontemboansch. & Tomboeloesch. & Bentenansch. & Bantiksch. \\
\hline 2 & 3262 & & & & \\
\hline 3 & 2358 & & & & \\
\hline 4 & 135 & & sapili Tom. & & \\
\hline 7 & 1961 & $\begin{array}{l}\text { wintangar } \\
\text { bitangar }\end{array}$ & $\begin{array}{l}\text { bintangar } \mathrm{T} 1 . \\
\text { bintangor } \mathrm{T} 1 .\end{array}$ & & \\
\hline 14 & 2175 & kowini & kowini & koewini & \\
\hline 18 & 602 & $\begin{array}{l}\text { kanari } \\
\text { reri }\end{array}$ & $\begin{array}{l}\text { reri } \\
\text { dedi Ts. } \\
\text { deri Tl. }\end{array}$ & & hihi \\
\hline & 614 & reri taranate & $\begin{array}{l}\text { reri taranate } \\
\text { dedi taranate } \\
\text { Ts. } \\
\text { deri taranate } \\
\text { T1. }\end{array}$ & & \\
\hline 25 & 665 & kapaja Wb. & & & \\
\hline- & & & & & \\
\hline 45 & 2004 & & & toehangka & toehangka \\
\hline 48 & 846 & & & & \\
\hline 51 & 2719 & , & laoembe Tom. & & \\
\hline 54 & 1799 & $\begin{array}{l}\text { kalimbaoe- } \\
\text { wang }\end{array}$ & $\begin{array}{l}\text { kalimbahoe- } \\
\text { wang T1. } \\
\text { kawaoean Ts. } \\
\text { wahoe } \\
\text { Bar. Wb. }\end{array}$ & & \\
\hline 58 & 2487 & iboeng Tsw. & & & \\
\hline 60 & 489 & & . & . & \\
\hline 62 & 1740 & & & & \\
\hline 65 & 1951 & $\begin{array}{l}\text { soekoer } \\
\text { soechoer } \\
\text { (Tsw) }\end{array}$ & 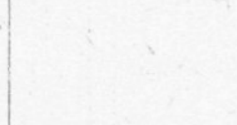 & & soekoehoe \\
\hline 66 & 2295 & & sampaka & & sampaka \\
\hline 68 & 3301 & & & & \\
\hline
\end{tabular}




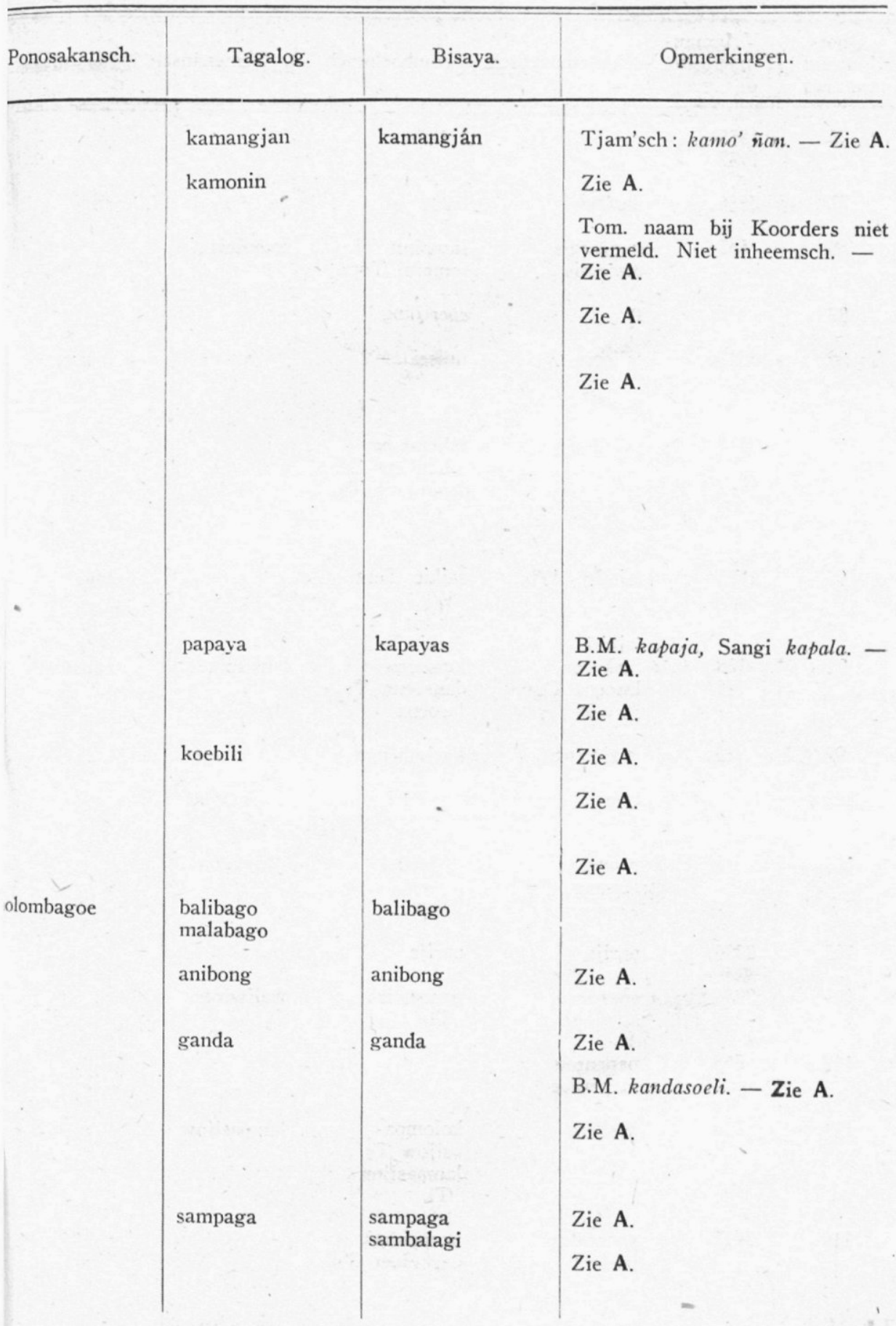




\section{B}

\begin{tabular}{|c|c|c|c|c|c|}
\hline $\begin{array}{l}\text { Door- } \\
\text { loopend } \\
\text { nummer. }\end{array}$ & $\begin{array}{l}\text { Volgnum- } \\
\text { mer wb. } \\
\text { de Clercq. }\end{array}$ & Tontemboansch. & Tomboeloesch. & Bentenansch. & Bantiksch. \\
\hline 75 & $\begin{array}{l}1555 \\
1987\end{array}$ & & kalating & & V \\
\hline 77 & 3556 & lia Tsw. & lia & fia & rija \\
\hline 86 & 532 & $\begin{array}{l}\text { tompingis } \\
\text { tompinis }\end{array}$ & $\begin{array}{l}\text { sampinit T1. } \\
\text { sompini Tom. }\end{array}$ & sompini & \\
\hline 87 & & - & soerijang & & \\
\hline 88 & 3313 & talisei & talisei & & tarisei \\
\hline 95 & 3153 & . & $\begin{array}{l}\text { lahendong } \\
\text { lahindong T1. } \\
\text { da'endong Ts. }\end{array}$ & & \\
\hline 96 & 1755 & laitjitj Wb. & $\begin{array}{l}\text { saikit Tont. } \\
\text { Wb. }\end{array}$ & & higi \\
\hline 98 & $\left\{\begin{array}{l}138 \\
141\end{array}\right.$ & $\begin{array}{l}\text { laisis " } \\
\text { laikitj " } \\
\text { lansoena } \\
\text { lasoena Tsw. }\end{array}$ & $\begin{array}{l}\text { lahikit } \\
\text { daikit Ts. } \\
\text { lansoena } \\
\text { dansoena Ts. } \\
\text { lasoena }\end{array}$ & lansoena & ransoena \\
\hline 99 & 22 & karimĕnga & karimběnga & , & \\
\hline 102 & & ra'ami & . & & \\
\hline 103 & & $\begin{array}{l}\text { rěwung } \\
\text { lěbuung }\end{array}$ & $y^{2}$ & & $v$ \\
\hline 105 & 2336 & parija & parija & & \\
\hline 109 & 2034 & roewiran & $\begin{array}{l}\text { panoewiran } \\
\text { T1. }\end{array}$ & waliwiran & \\
\hline 112 & 568 & $\begin{array}{l}\text { papentoe } \\
\text { mapentoe }\end{array}$ & & & \\
\hline 114 & $\begin{array}{r}710 \\
\ldots\end{array}$ & pasijow & $\begin{array}{l}\text { kolompa- } \\
\text { sijow Ts. } \\
\text { lampasijow } \\
\text { T1. }\end{array}$ & lampasijow & . \\
\hline 119 & 3417 & $\begin{array}{l}\text { poepoeloet } \\
\text { poeloet }\end{array}$ & $\begin{array}{l}\text { poepoejoet } \\
\text { papoejoet Ts. }\end{array}$ & & \\
\hline
\end{tabular}




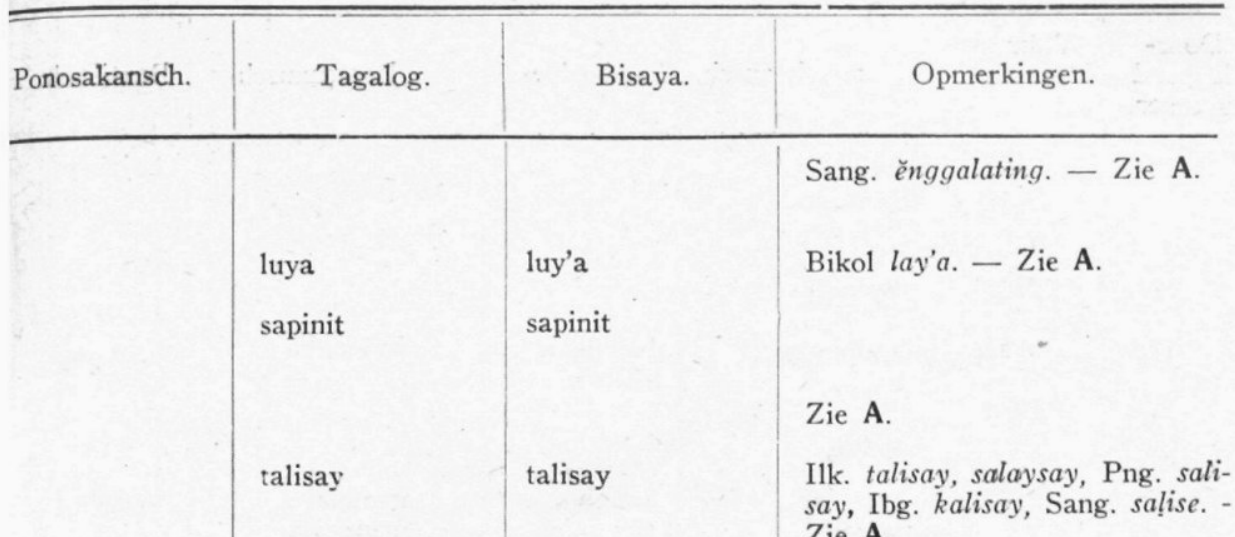
Zie A.

Zie A.

Insoena

\begin{tabular}{|l|l} 
lasonâ & lasona \\
dayami & dayami \\
labóng & $\begin{array}{l}\text { labong } \\
\text { dabong }\end{array}$
\end{tabular}

B.M. jantoena. - Zie A.

Bare'e kariango. - Zie A.

Mgd. lagami, ragami, Sang. dahami. - Zie A.

Ilk. rabong, Bkl. ramboeng, Png. Pamp. laboeng, Ibg. raboeng. - Zie A.

Zie A.

Sang. baloebirang.

Zie A.

Zie A.

D1. 101. 
GELIJKHEID EN VERSCHIL VOORVOEGSELS IN INDONESISCHE TALEN.

B

\begin{tabular}{|c|c|c|c|c|c|}
\hline $\begin{array}{l}\text { Door- } \\
\text { loopend } \\
\text { nummer. }\end{array}$ & $\begin{array}{l}\text { Volgnum- } \\
\text { mer wb. } \\
\text { de Clercq. }\end{array}$ & Tontemboansch. & Tomboeloesch. & Bentenansch. & Bantiksch. \\
\hline 123 & 2862 & $\begin{array}{l}\text { kajawas } \\
\text { kowajas } \\
\text { kojawas }\end{array}$ & & & kojabasa \\
\hline 124 & 2783 & walontas & & & \\
\hline 125 & $\begin{array}{r}-934 \\
784 \\
1973\end{array}$ & walongka & $\begin{array}{l}\text { balongka } \\
\text { Tom. }\end{array}$ & walongka & \\
\hline 126 & 3557 & $\begin{array}{l}\text { walěgai } \\
\text { wagělei }\end{array}$ & $\begin{array}{l}\text { banglai } \\
\text { wangalei }\end{array}$ & $\begin{array}{l}\text { manglai } \\
\text { mangoelai }\end{array}$ & bangĕrei \\
\hline 127 & 2736 & marisa & marisa & & hisa \\
\hline 131 & $\begin{array}{l}2478 \\
2479\end{array}$ & wěnoang & $\begin{array}{l}\text { běnoang T1. } \\
\text { wěonang ", }\end{array}$ & winoeang & \\
\hline 133 & 589 & $\begin{array}{l}\text { wintangor } \\
\text { Wb. }\end{array}$ & $\begin{array}{l}\text { wintaoe } \\
\text { bintaoe } \mathrm{T} 1 .\end{array}$ & & \\
\hline 136 & 1796 & koeranga & koeranga & & boehanga \\
\hline 137 & 2343 & $\begin{array}{l}\text { popo'du Wb. } \\
\text { popo'ndu ", } \\
\text { bokoedoe } \\
\text { Tsw. }\end{array}$ & & & \\
\hline 138 & 2532 & & & & \\
\hline 146 & 2289 & roembia $\mathrm{Wb}$. & & & \\
\hline 148 & 178 & $\begin{array}{l}\text { wariangow } \\
\text { Wb. } \\
\text { marijangow } \\
\text { Wb. } \\
\text { lijacho Tsw. }\end{array}$ & $\begin{array}{l}\text { barijango } \\
\text { warijango } \mathrm{Tl} \text {. } \\
\text { rariangow } \mathrm{T} 1 .\end{array}$ & & \\
\hline 149 & 1233 & $\begin{array}{l}\text { alipoengoe } \\
\text { Wb. } \\
\text { lalipoengoe } \\
\text { Wb. }\end{array}$ & $\begin{array}{l}\text { aripoengoe } \\
\text { raripoengoe } \\
\mathrm{T} 1 .\end{array}$ & & \\
\hline 150 & 532 & & $\begin{array}{l}\text { roeroendoe } \\
\text { raroendoe Ts. }\end{array}$ & & \\
\hline 151 & 3473 & & lagoende Tl. & & \\
\hline 153 & 1897 & & & & \\
\hline 154 & 3552 & & & & \\
\hline 158 & 159 & lintjoewas & $\begin{array}{l}\text { lingkoewas } \\
\text { T1. }\end{array}$ & & ringkoewas \\
\hline 159 & 1486 & langoesei & $\begin{array}{l}\text { (beren, weren) } \\
\text { koese }\end{array}$ & $\begin{array}{l}\text { mahang- } \\
\text { koese }\end{array}$ & \\
\hline
\end{tabular}




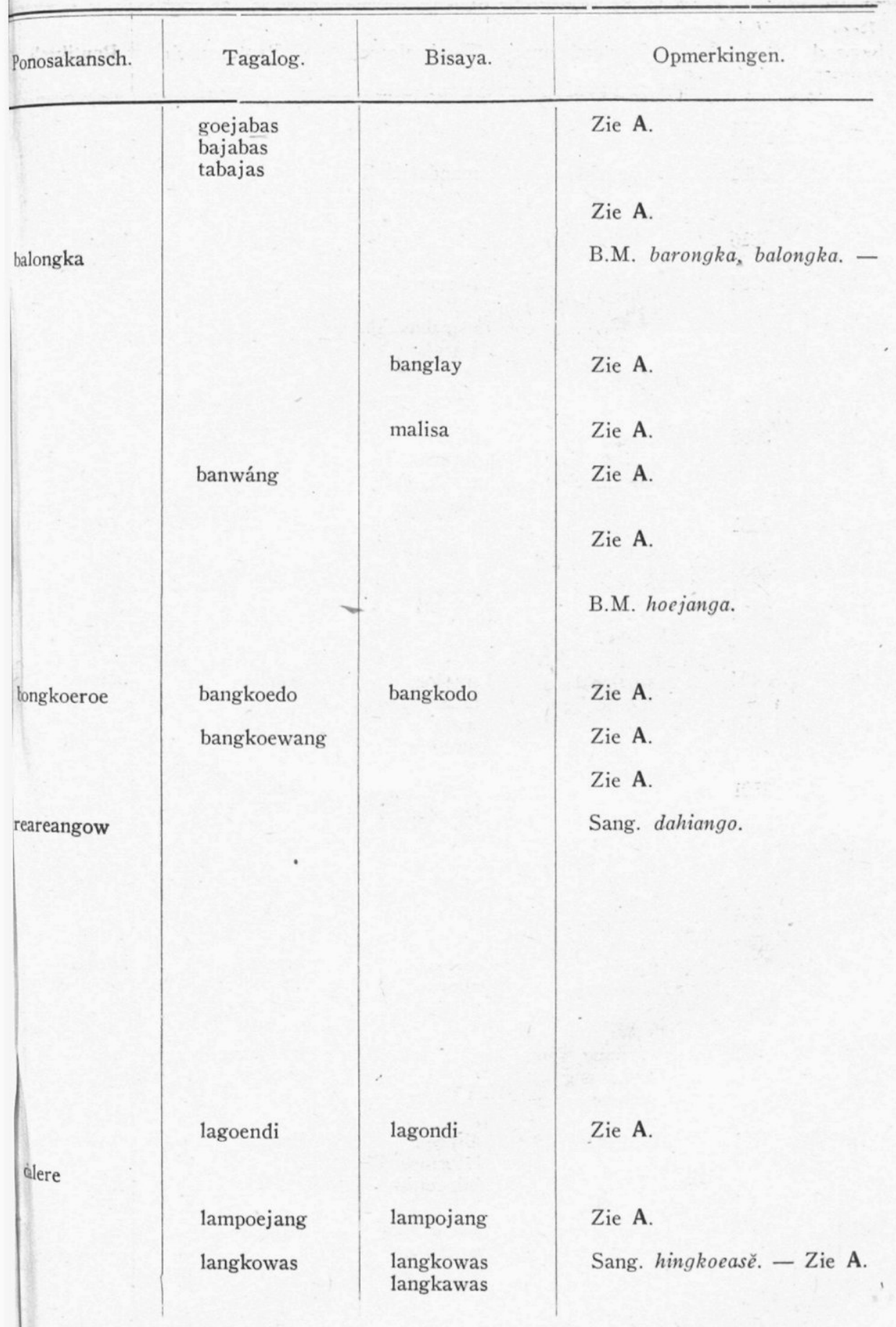


B

\begin{tabular}{|c|c|c|c|c|c|}
\hline $\begin{array}{l}\text { Door- } \\
\text { loopend } \\
\text { nummer. }\end{array}$ & $\begin{array}{l}\text { Volgnum- } \\
\text { mer wb. } \\
\text { de Clercq. }\end{array}$ & Tontemboansch. & Tomboeloesch. & Bentenansch. & Bantiksch. \\
\hline 163 & 151 & & & - & \\
\hline 165 & 2281 & manaring & $\begin{array}{l}\text { mandaring } \mathrm{Tl} \text {. } \\
\text { wanaring Ts. }\end{array}$ & & \\
\hline 166 & 816 & parata $\mathrm{T}_{\text {sw. }}$ & & wanatit & banata \\
\hline 168 & :084 & & $\begin{array}{l}\text { koemarakas } \\
\text { T1. } \\
\text { marakas T1. } \\
\text { warakas T1. } \\
\text { koemaraskas } \\
\text { Ts. }\end{array}$ & & \\
\hline 175 & 3088 & $\begin{array}{l}\text { rijat } \\
\text { salaot Tsw. } \\
\text { laloempe' }\end{array}$ & $\begin{array}{l}\text { dijat } \\
\text { sarawet T1. } \\
\text { sarait Ts. }\end{array}$ & & \\
\hline 176 & 2661 & & & & \\
\hline 185 & 2636 & & & & \\
\hline 194 & 2474 & $\begin{array}{l}\text { koelasi } \\
\text { soelasi }\end{array}$ & - & & \\
\hline 196 & $\left\{\begin{array}{l}404 \\
407 \\
413\end{array}\right.$ & $\begin{array}{l}\text { woeloe'd } \\
\text { boeloe Tsw. }\end{array}$ & $\begin{array}{l}\text { woeloe } \\
\text { tabalo Tom. } \\
\text { walo } \\
\text { woedoe Ts. }\end{array}$ & woelve & boero \\
\hline 197 & 3501 & & $\begin{array}{l}\text { dànoi Ts. } \\
\text { lah oenoei }\end{array}$ & oenei & \\
\hline 201 & 1666 & $\begin{array}{l}\text { wěnganga } \\
\mathrm{Wb} \text {. }\end{array}$ & . & . & \\
\hline 203 & 836 & talĕnde & & & \\
\hline 204 & 1514 & awělas & $\begin{array}{l}\text { awělas } \\
\text { alěwas Ts. } \\
\text { (Wb.). }\end{array}$ & woelas & barasa \\
\hline 208 & 878 & $\begin{array}{l}\text { anonang Tsw. } \\
\text { manonang ," } \\
\text { nonang ", }\end{array}$ & . & $\begin{array}{l}\text { manonang } \\
\text { nonang }\end{array}$ & \\
\hline 218 & 701 & laloempe' & $\begin{array}{l}\text { alipega } \\
\text { laloempe T1. } \\
\text { laloempehe. }\end{array}$ & lipoga & \\
\hline 219 & 1573 & amreroeng & $\begin{array}{l}\text { amoeroeng } \\
\text { woeroeng } \mathrm{T} 1 . \\
\text { woedoeng } \mathrm{Ts} \text {. }\end{array}$ & & \\
\hline
\end{tabular}


GELIJKHEID EN VERSCHIL VOORVOEGSELS IN INDONESISCHE TALEN. 379

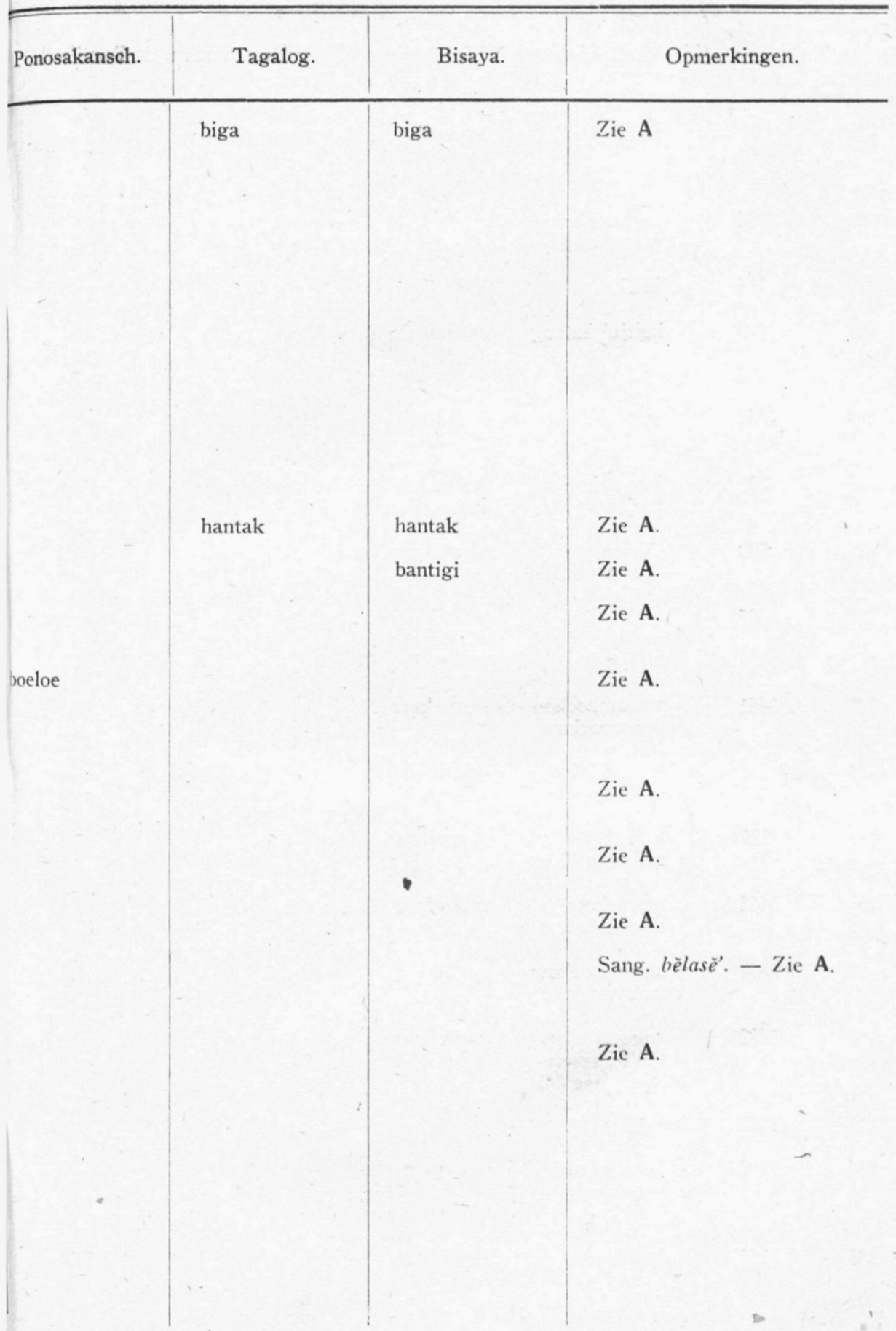


B

\begin{tabular}{|c|c|c|c|c|c|}
\hline $\begin{array}{l}\text { Door- } \\
\text { loopend } \\
\text { nummer. }\end{array}$ & $\begin{array}{l}\text { Volgnum- } \\
\text { mer wb. } \\
\text { de Clercq. }\end{array}$ & Tontemboansch. & Tomboeloesch. & Bentenansch. & Bantiksch. \\
\hline 220 & & poeni & $\begin{array}{l}\text { apoene' } \\
\text { lampoeni Td. } \\
\text { (Bare'e wb) }\end{array}$ & ' & \\
\hline 221 & 2984 & $\begin{array}{l}\text { karangeian } \\
\text { saroerangei }\end{array}$ & & & \\
\hline 222 & 1166 & koili & kaili Tom. & & \\
\hline 223 & 2497 & $\begin{array}{l}\text { koitjo' batang } \\
\text { koitjo' } \\
\text { mbatang }\end{array}$ & sarimbata $\mathrm{Tl}$. & & \\
\hline 224 & 1444 & $\begin{array}{l}\text { tareran Wb. } \\
\text { kareran ", }\end{array}$ & & & \\
\hline 225 & 707 & $\begin{array}{l}\text { lampasiow } \\
\text { pasiow }\end{array}$ & $\begin{array}{l}\text { kolompasijow } \\
\text { lampasijowT1. }\end{array}$ & lampasijow & \\
\hline 226 & 580 & $\begin{array}{l}\text { lintjaren } \\
\text { lingkaren }\end{array}$ & dingkaran Ts. & & \\
\hline 227 & 1605 & $\begin{array}{l}\text { makawilei } \\
\text { mongombilei } \\
\text { Tsw. }\end{array}$ & $\begin{array}{l}\text { mahakawilei } \\
\text { makawidei T1. } \\
\text { makawilei T1. }\end{array}$ & & \\
\hline 228 & 1461 & $\begin{array}{l}\text { masamboekow } \\
\text { masawoekow }\end{array}$ & sawoekow T1. & & \\
\hline 229 & & $\begin{array}{l}\text { paroendak } \\
\text { Wb. }\end{array}$ & $\begin{array}{c}\text { waroendak } \\
\text { Tnt. Wb. }\end{array}$ & & \\
\hline 230 & 229 & $\begin{array}{l}\text { salimbata' } \\
\text { salimata Tsw. }\end{array}$ & sarimbata' & & \\
\hline 231 & 1461 & $\begin{array}{l}\text { sawoekow } \\
\text { samboekow } \\
\text { Wb. } \\
\text { masamboekow } \\
\text { masawoekow }\end{array}$ & sawoekow T1. & - & \\
\hline 232 & 2482 & $\begin{array}{l}\text { tagoelaindang } \\
\text { Wb., tawoe- } \\
\text { laindangWb. }\end{array}$ & $\begin{array}{l}\text { tapoelandang } \\
\text { Tont. Wb. }\end{array}$ & & \\
\hline 233 & (539) & taisi & & & \\
\hline 234 & 3196 & $\begin{array}{l}\text { kataliawan } \\
\text { tataliawan } \\
\text { Wb. }\end{array}$ & $\sqrt{2}$ & & - \\
\hline 235 & 1153 & tongkoate & longkoate $\mathrm{T} 1$. & & \\
\hline
\end{tabular}


GELIJKHEID EN VERSCHIL VOORVOEGSELS IN INDONESISCHE TALEN. 381

B

\begin{tabular}{|l|l|l|l}
\hline \hline Ponosakansch. & Tagalog. & Bisaya. & Opmerkingen. \\
\hline
\end{tabular}

dingkalin

dangkalan

Sang. dingkaleng.

Sang. sahtst 
B

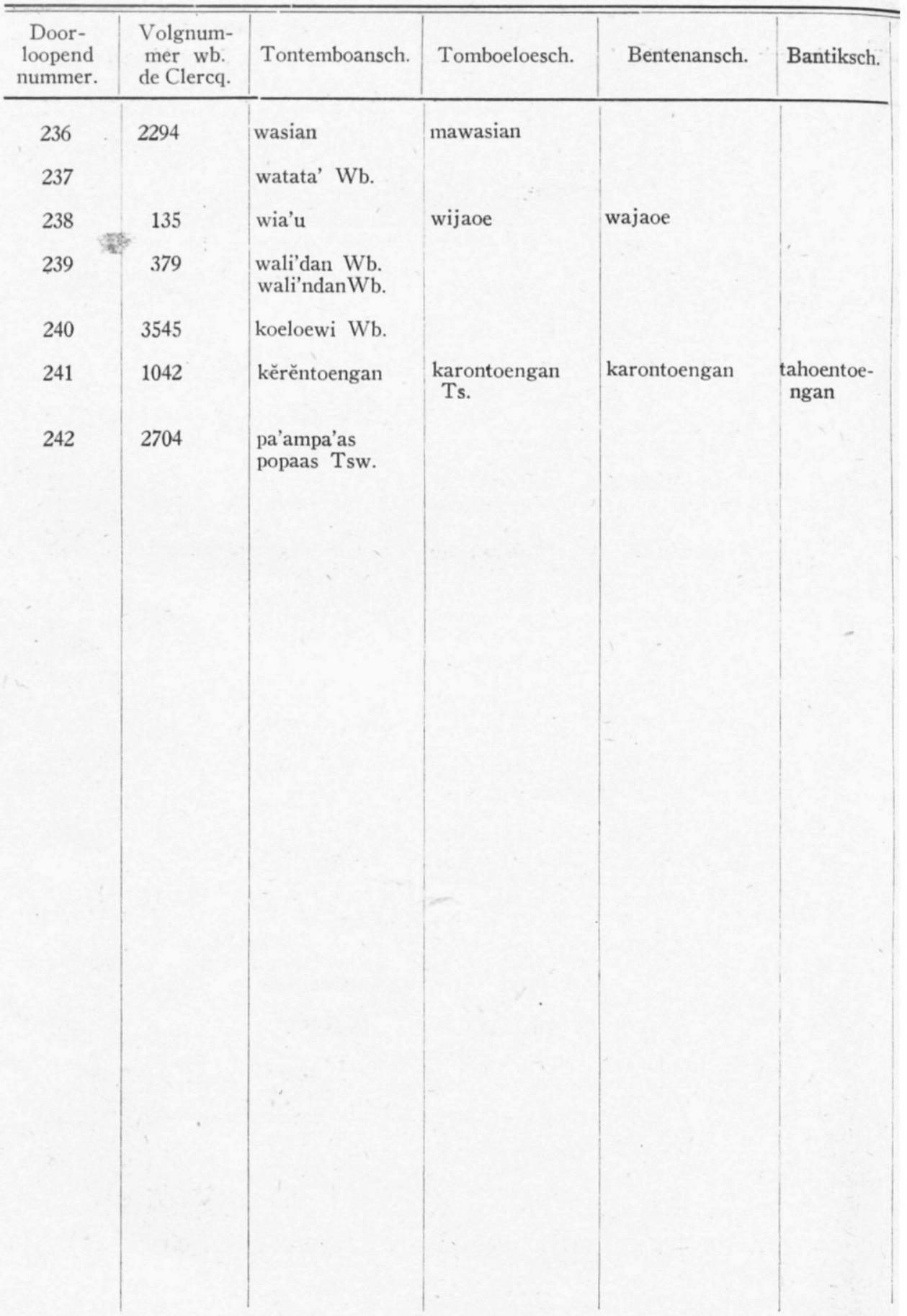


GELIJKHEID EN VERSCHIL VOORVOEGSELS IN INDONESISCHE TALEN. 383

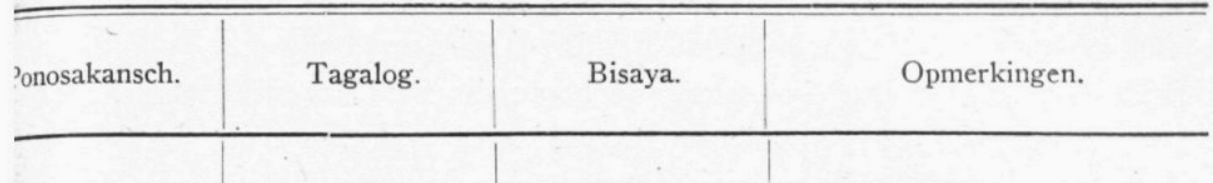

Sang. batata'.

Saleyer poelirang.

Zie A. 


\section{AANTEEKENINGEN.}

A B 2. Jav. mĕnjan enz. is benzoë, de boom die haar levert, heet kajoe mĕnjan (Jav.), ki mĕnjan (Soend.) enz.

A B 4. Grondwoord is *biri, *piri. Zie voor den Minahasischen, inheemschen naam No. 238.

A 5. In Jav. gaděle is ga geen zelfstandige aanwijzer, maar eẹn zwakkere uitspraak van $k a$.

A B 7. Grondwoord van Tont. wintangar, Tsw. bitangar, is *tangar.

- Een voorvoegsel kati- komt bij plantennamen wel voor, toch schijnt de grondvorm van Mal. katimahar niet mahar te zijn, maar *tahar met een oud, niet meer bekend infix -im-. Zoo ook Jav. katimanga van *tanga en katimaha van *taha, Jav. en Bat. hebben de $-r$ afgeworpen. Het Mad. heeft de neiging woorden te verkorten door weglating der eerste lettergreep of lettergrepen, vandaar mangar, doch de slot $-r$ is behouden.

A 8. Jav. kapidada toont een dubbelen aanwijzer.

A 9. Ook katjapiring heeft een dubbelen aanwijzer. Het is niet noodig daar telkens op te wijzen, het komt herhaaldelijk voor. patjiring is Oost-Javaansche omzetting van tjapiring. In het algemeen onderscheidt zich het Oost-Javaansch van het gewone Javaansch door deze neiging.

A 10 . Gw. is *birit, de uitspraak tjampirit schijnt onder invloed van de voorafgaande $t j a$ te zijn ontstaan. De verzachting van $k a$ tot ga en tja tot $d j a$ vóór $b i$ is de omgekeerde werking.

A 12. Soend. koetjoeboeng levert een voorbeeld van assimilatie van den klinker van den aanwijzer aan de vocaal van het grondwoord.

A 13. katoembar (coriander) wordt in het Jav. wb. van Skr. kutumburu afgeleid, dit kan echter niet juist zijn blijkens Soend. katoentjar waarin volgens een Indonesische klankwet tjar correspondeert met Jav. ${ }^{*}$ war, dit met prenasaleering geeft mbar. - Boeg. katoembara' moet uit het Mak. zijn overgenomen.

A 16. Jav. katilajoe toont den aanwijzer $k a$-, de functie van $t i$ is onzeker.

A B 18. kanari schijnt gevormd uit $k a+$ geprenasaleerd dari, waarbij de beginconsonant in de nasaal is opgelost. Kandari komt als plaatsnaam op de Oostkust van den zuid-oostelijken arm van Selebes voor. Wat Tont. reri betreft, in deze taal is $r$ aan het begin van een woord de vervangster van $d$.

A 19. Grondwoord is *bĕta, *běnta, met dubbel voorvoegsel. $K a$ - is 
aanwijzer, la komt in de Indonesische talen als aanwijzer voor, in de Woordenlijst zijn daarvan voorbeelden gegeven, doch la (li) kan ook formatief zijn, hoewel thans in het Javaansch niet bekend. Het laat zich niet uitmaken met welk $l a$ men hier te doen heeft.

A 20. Jav. kalesĕm is samentrekking van kali asĕm.

A 23. Prakr. kanigara is de zonnebloem (Nymphaea stellata Wild.), Jav. kanigara is een boom met gele bloemen (Cochlospermum balicum Boerl.).

A B 25. Het woord papaja schijnt uit West-Indië gekomen te zijn (Hobson- Jobson s.v. papaya) 't Valt op, dat uiteenloopende talen als Jav. en Mal, en Tont. en Bisaya het woord op dezelfde wijze indonesisch hebben gemaakt.

A 26. Mad. kamodoeng gaat terug op een vorm waarin de nasaal verschoven is, $\mathrm{ka}+$ poe + ndoeng $>\mathrm{ka}+$ mpoe + doeng $>$ kamoedoeng, Mad. $o .=$ Jav. oe.

A 30. Het is waarschijnlijk dat Jav. badali niet den aanwijzer $b a$ draagt, maar een zwakkere uitspraak is van padali, cf. Soend.

A 32. Grondvorm schijnt te zijn laka, in Jav. en Bal. met aanwijzer $\mathrm{ka}+$ actief-prefix. Over het actief-prefix vóór plantennamen zal later gesproken worden. - Bal. kalimaka is omzetting van kamilaka, zoo ook Sas. lameke en lamaka.

A 39. Hier schijnt geen aanwijzer $k a$ aanwezig te zijn maar Jav. kamadoehan enz. gaat waarschijnlijk terug op *kadoeh met een oud infix -am-; *kadoeh correspondeert met *kandeuh (de prenasaleering speelt geen rol), waarvan Soend. mangandeuh. De vocaal in de tweede letergreep wisselt, $o e=$ Soend. $e u$, waarnaast $i(e)$.

A 40. olakambing, als Oost-Javaansch opgegeven, ziet er verdacht uit. A 47. Het Soend. wb. geeft i.v. koedrang: extract van tjangkoedoebast met aluin en andere bestanddeelen, dienende om garen te kleuren. - Het M.K.'sç wb. onderscheidt : koedarang - zeer donker bruin of blauw, tegen het zwarte aan en glanzend, kaderang - boom waarvan het hout een gele verfstof levert.

A B 48. Bij de Clercq is Jav. gambili enz. een kruid waarvan de knollen gegeten worden. Soend. hoewi koeměli is de benaming van onzen aardappel. - Tag. koebili wordt beschreven als een eetbare vrucht, gelijkend op eikel en kastanje, dit moet een andere plant zijn maar etymologisch is 't hetzelfde woord.

Jav. gambili kan een zwakkere uitspraak van *kambili zijn, maar 
voor Bandjarsch gombili, Dajaksch gambili gaat dit niet op, hier is de aanwijzer go- resp. ga. - Grondwoord is *bili, *běli.

A 52. In het Javaansch wordt in den aanwijzer wel eens een looze $r$ ingeschoven: kroembang $={ }^{*}$ koembang; tranggoeli $=$ tanggoeli; srigoenggoe = sagoenggoe, evenzoo in het Baliesch.

A B 54. De Clercq (Koorders) geeft nog op: Tont. baoe, een onbestaanbaren vorm. In Tomb. is $h$ de representant van de $r-g$ - $h$ klank, in Tont. wordt zij hamzah of verdwijnt.

A B 58. Grondvorm is *diboeng, *liboeng.

A 59. In ganitri, hoewel uit het Sanskr. overgenomen, wordt in het Jav. en in het Soend. de eerste syllabe verwisseld als ware zij een indonesische aanwijzer; $d j i$ in plaats van $d j a$ is een assimilatieverschijnsel. - Mal. gandatěri schijnt dezen vorm onder invloed van andere met ganda samengestelde namen te hebben aangenomen.

A 61. De naam gandaroesa komt ook in de Minahasische talen voor maar als vreemd woord.

A B 65. Jav. kĕntjoer is omzetting van tjĕkoer met prenasaleering. In Soend. tjikoer is $i$ vóór oe in de volgende lettergreep uit $\breve{e}$ ontstaan, vgl. tizwoe Jav. těboe. Voor Dairi-Bataksch kĕtjeoer (onregelmatig), zie van der Tuuk, Tobasche Spraakkunst I 9.

A B 66. Sampaka is door het Mal. in de Minahasische talen gekomen, tja wordt $s a$, ook in de Filippijnsche talen en in het Bataksch. Het woord is Sanskr. campaka. Het Sawoe'sch heeft hăpaka, kăpaka; $h$ is representant van een oudere $s$ en $s$ vervangt $t j$, maar kăpaka is zelfstandig gevormd van een z.g. grondwoord *paka met aanwijzer $k a$.

A B 68. kamalagi is Oud-Javaansch, over als plaatsnaam, Ibg. kalamagi is hetzelfde met omzetting. - M.K. tjoemalagi $=$ òf tjalagi met infix -oem-, dat bij plantennamen wel eens voorkomt in de beteekenis ,zich voordoende als”, ,zijnde”, ò het is z.v.a. tjamalagi, wat op tja + (geprenasaleerd) mbalagi teruggaat. Vrg. Bis. sambalagi. Gw. is dus lagi, aanwijzers zijn tja en sa. Hiervoor worden weder aanwijzers geplaatst, zoodat dubbele aanwijzers ontstaan, wat wel eens meer voorkomt: $k a$ (Jav.), sa (Bis., ook Bare'e sambalagi, sombalagi). Il. heeft met oplossing van $b$ in de prenasaleering en omzetting salamagi.

Mak. tjamba, Boeg. tjĕmpa beantwoordt aan het eerste deel van Bis. Bar. sambalagi, lagi is afgeworpen. Men heeft den naam, 
naar het schijnt, als uit twee woorden bestaande opgevat en het eerste behouden.

A 69. Daj. toewada ziet er uit alsof het van de Bandjareezen (tiwadak) is overgenomen en eigenlijk toewadak of toewada' luidt. Grondvorm is, zie Bataksch, *bědak en dan doet zich het merkwaardige verschijnsel voor dat de muta na prenasaleering tot tenuis wordt verhard; in het Boegineesch is dit vaste regel, elders is het onbekend behalve in een paar plantennamen (aanwijzer + geprenasaleerd gw.). Eenige onzekerheid blijft bestaan wegens Mal. Bangkalis tjapĕdak. Zoo dit niet staat voor tjampědak, zou men misschien een bijvorm *pědak moeten aannemen, doch dan blijft ook nog de mogelijkheid dat $b$ onder invloed van voorafgaande $\mathrm{tj}$ tot $p$ is verhard. Vgl. boven, aanteekening bij A 10.

A 70. Bat. tandohan, volgens E. een bepaalde soort paddestoel, dan -paddestoel in het algemeen.

A B 77. Mal. [h] ahija is omgezet *lahija. Het Oud-Jav. luidt jahya (djahja). Grondvorm is *hya. Het Baliesch toont het gw. met beide aanwijzers: $d j a$ en $l a$.

A 81. Nos. 683 en 1184 de Cl. zijn verschillende planten hoewel de determineering van de laatste nog niet vaststaat, maar etymologisch zijn de namen gelijk. - Nos. 1184 en 1190 zijn verwante planten.

A 83. tanalajoe is een soort droogbloem. Gw. is lajoe - verwelkt, $t a$ - is hier passief-prefix, niet aanwijzer, en bovendien van een niet meer bekend infix -an- voorzien. De namen zijn OostJavaansch. In het algemeen zijn hier de vokalen, ook van aanwijzers, minder vast dan in het gewone Javaansch.

Ook tinggoeloen (A 82) is Oost-Javaansch, $a$ in de derde lettergreep van achteren gaat meer in $i$ over, men zegt widana voor zeradana.

A 85. Gw. boekoes. Jav. koemoekoes toont volkomen prenasaleering en assimileering van de vocaal van den aanwijzer $k a$ aan de vocalen van het gw.

A B 87. Soend. toerijang - opslag op de sawah; Karo Bataksch idem, nakomende rijstaren; Boeg. soerijang - de arenpennen die uit het doek-weefsel om den stam steken; Tb. soerijang, gw. --- nalezen, aren lezen. 
A 92. Het melksap van dezen boom maakt blind (boeta), de naam is daarvan afgeleid.

A 93. Grondvormen zijn lijĕn, lin, ělin.

B 95. In dit geval zijn la en $d a$ niet twee verschillende aanwijzers, maar is het een bekende klankverwisseling.

A B 96. In het Tontemboansch gaat $k$ na $i$ in $t j a$ over, dialectisch geschiedt dit niet.

A B 98. Skr. rasuna. Nos. 138 en 141 de Cl. zijn beiden Alliumsoorten. In B.M. wisselt $r$ met $j$, in de Minahasische talen $r$ met $l$.

A B 102. Mak. ra wisselt met Boeg. $d a$; Mdg. la beantwoordt soms aan Mal. da en omgekeerd.

A B 103. In Soend. iwoeng is $i$ uit $\breve{e}$ ontstaan. Vgl. aanteekening bij A B 65. - Bis. labung, Bk1. rambung wordt van spruiten in het algemeen gezegd.

A 108. lotjari is Oost-Javaansch. Mogelijk te lezen lå tjari, als twee woorden uitgesproken, dan zou 't de aanwijzer la zijn.

A 121. Oud-Javaansch panggaga, het Baliesch heeft, als meermalen, den ouderen vorm bewaard. Bataksch ampagaga toont een dubbelen aanwijzer.

A B 123. De Tontemboansche naam is afgeleid van guyabas, een vruchtboom uit Spaansch Amerika ingevoerd, naar de Spaansche uitspraak. Het Tagalog heeft het woord geindoniseerd.

A B 125. de Cl. 934 komkommer, 784 watermeloen, 1973 fleschkalibas, behooren tot verschillende plantenfamilies maar zijn voor een leek soortgelijke planten. Tont. walongka wordt opgegeven voor No. 1973, Tom. balongka voor No. 934, 784, Bent. walongka voor No. 1973, Ponos. balongka voor No. 1973, B.M. barongka voor No. 784, balongka voor No. 1973.

A B 126. De Tontemboansche en de Tomboeloesche namen loopen bij de Clercq en Koorders uiteen; de eerste geeft Tont. wagělei, de tweede banggalei, banggělai, geen van beiden bestaanbaar. De juiste vorm is volgens het $\mathrm{Wb}$. walĕgai, een omzetting van wagĕlai. - Voor Tomb. geeft de Cl. dial. T1. bangělei, banglaj wangělei, Koorders banglai, wangalei. Grondvorm is lai, ělai.

A B 127. Skr. marica. Opmerkelijk is Boeg. baritja, als van een quasi-Indonesisch *ritja gevormd.

A 129. Jav. badali is een zwakke uitspraak van padali, aldus in het Oud-Jav. en in het Soend. Roorda geeft nog op goedali. 
A B 131. Naast Tont. wěnoang vermeldt het Wb. nog mawěnoang, naar het schijnt, een anderen boom.

A 134. Skr. badara, Oud-Jav. wadara.

A B 137. Soend. tjangkoedoe vooronderstelt Jav. *wangkoedoe (zie boven aanteekening bij A 13), dat echter niet bekend is, maar in het Baliesch, met assimilatie van de vocaal, is bewaard als woengkoedoe. - Jav. kěmoeḍoe kan zijn koeḍoe met een oud -am- of met -am-infix.

A 138 en 139. Zijn verschillende gewassen maar de namen bevatten allen hetzelfde gw.

A 146. In het Dajaksch wordt de $r$ van verwante talen soms gerepresenteerd door $h$, de aanwijzer $h a<r a$ valt dan samen met oorspronkelijk ha.

A 147. de Cl. geeft Soend. lampani, mij slechts bekend als lampěni.

B 148. Tomb. barijango, warijango. T1. waarschijnlijk bariangow, wariangow te lezen.

A 157. Misschien behoort hier ook toe Karo-Bat. galoenggoen ,,zekere struik”. J.

A B 158. Grondwoord schijnt te zijn *was, waarvan met tweeërlei voorvoegsel *kawas en *lawas, wat in het Lamp. voorkomt, Jav. laos. — Van *kawas, *koewas zijn door voorvoeging van den aanwijzer la $(l i)$ en prenasaleering de meeste bestaande vormen afgeleid. Toba-Bataksch halás $<$ halaas $<*$ halawas, de $w$ moet in deze taal tusschen twee klinkers uitvallen (van der Tuuk, Tobasche Spraakkunst I 13). De Cl. geeft als Bataksche benaming ook halawas, dit kan noch Tobaasch noch Mandailingsch zijn, evenmin Dairisch of Karoosch, want dezen dulden $k a$ (of $k \breve{e}$ ) aan het begin van een woord.

A 169. Daar Soend. $t j a=$ Jav. $w a$ is de aanwijzer in beide talen dezelfde.

A 171. Oud-Jav. wadoeri.

A B 176. Bij Bal. [h] atak vermeldt het K. B. Wb. nog tak, Sarawak Dajaksch rětak, Tjam. ratap, doch ook ratak komt daar voor, zie Wb. Aymonier en Cabaton, s.v.; voorts Mlg., volgens Flacourt, antak, Sasaksch antap. Ook wordt harětak s.v., zonder toelichting vermeld. Grondvorm schijnt dus te zijn tak, met aanwijzer hatak, waarnaast een breedere vorm rětak, met aanwijzer harětak. Nevenvorm van tak is tap. Tag. en Bis. voegen nog prenasaleering in.

A 181. De gewone benaming in het Soendaasch is sadagori. 
A 183. Mal. samaram is te verklaren als $\mathrm{sa}+$ geprenasaleerd *baram, sambaram $>$ samaram.

A 189. De nummers 2894 en 2709 bij de Clercq behooren tot verschillende plantenfamilies, maar worden beiden als pinangsoorten beschouwd. Mal. sinazar $=s i+$ geprenasaleerd dawar. Soend. sinagar kan ik niet verklaren.

A B 194. Skr, toelasi.

A 198. Soend. toeralak is duister. Volgens het wb. is toeralak = boerahol, volgens de $\mathrm{Cl}$. zijn dit twee verschillende planten.

A 200. Men kan hier ook aan een infix -am-, -im- denken.

A B 204. Grondvorm is *bĕlas, *wĕlas; na prenasaleering zou men $m b$. verwachten, doch de muta wordt tot tenuis verhard. Zie hiervoor de aanteekening bij A 69.

A 212. Mal. gaharoe vermoedelijk door omzetting van $[\mathrm{h}]$ agaroe ontstaan.

A 213. Oud-Javaansch hambawang.

A 216. Oud-Jav. halalang.

B 226. dingkaran Ts., dus: dingkaren?

In het algemeen kan gezegd worden dat alle aksara's die aan het begin van een woord kunnen staan, als aanwijzer voorkomen, met één groote uitzondering: de nasalen (nga, nja, na, ma) treden niet, als aanwijzer op. Voorts ontbreekt algemeen $j a^{1}$ ), dit laatste hangt hiermede samen dat in echt-Indonesische woorden $j a$ - als beginconsonant zeldzaam is. De meeste met $j a$ beginnende woorden zijn aan Sanskrit of Arabisch ontleend. Is $j a$ echter uit een andere klank ontstaan, dan kan zij wel openaar zijn en komt zij ook als aanwijzer voor, dit doet zich o.a. voor in het Bolaang-Mongondow'sch en het Bare'e.

Komt in een bepaalde taal een zekere consonant weinig aan het begin van een woord voor, zooals $w$ in Maleisch en Dajaksch, dan víndt men de aksara ook niet als aanwijzer. Het Javaansch kent alleen de dentale $d$ en $t$ als aanwijzer, niet de palatalen.

Als regel is de aksara-aanwijzer lĕgĕna, heeft dus de $a$-klank. Andere klinkers komen voor $(i, o e)$, een zelfde plant heeft een aanwijzer met $a$ in de eene, met $i$ in de andere taal, over en weer, ook meer dan één klinker in dezelfde taal, 't is duidelijk dat men hier met bijvormen te doen heeft, die zich in functie of beteekenis in geen

1) Met één uitzondering: Bat. jangdoedoe $=$ andoeroe, de C1. 674 . 
enkel opzicht van den normalen vorm onderscheiden. Voorbeelden levert de Woordenlijst.

M.m. valt hetzelfde te zeggen van een ander verschijnsel, de prenasaleering. Vaak toch wordt tusschen aanwijzer en eigenlijk grondwoord een nasaal geschoven, soms volkomen nasaleerend $(m p>m$ enz.), soms onvolkomen ( $m p$ blijft $m p$ ). Er is op te merken dat deze prenasaleering na één aanwijzer meer in zwang is dan na een anderen, de eene consonant toont meer neiging tot prenasaleering dan de andere, kortom, deze is zuiver fonetisch van aard en heeft verder geen grammatische beteekenis. Dit blijkt ten overvloede hieruit dat geprenasaleerde en niet-geprenasaleerde vorm naast elkaar in dezelfde taal voorkomen.

De Woordenlijst doet verder zien dat soms de naam van een plant met een zelfden aanwijzer door vele talen gaat, dan weer verschillende talen bij denzelfden grondvorm verschillende aanwijzers bezigen, ten slotte een grondvorm met verschillende aanwijzers tegelijkertijd in zekere taal in gebruik is.

Alle aksara lĕgĕna met modificaties zijn dus als aanwijzer gelijkwaardig, of, anders gezegd, allen hebben gelijke, demonstratieve kracht.

Een groot aantal plantennamen heeft als eerste syllabe $m a$-, dit schijnt in tegenspraak met wat boven omtrent de nasalen werd gezegd. $M a$ - is echter niet aanwijzer maar het gewone actief-prefix. In de Filippijnsche talen zijn de namen van met mala-, mara- samengestelde namen zeer talrijk. De beteekenis is : ,er uitziende als, den indruk „,wekkende van, gelijkende op”, b.v. Tag. malaboho - een plant gelijkend op boho (bamboe); malaboelak - een plant gelijkend op boelak (kapok); malaboenoet - een plant die aan boenoet (kokosvezel) doet denken; Iloko maratabako, marakapas, maramabolo - planten die gelijken op resp. tabak, katoen, mabolo (een harige vrucht); Pamp. malaroehat - gelijkend op doehat; malaiking poesa - plant gelijkend op een kattenstaart; Bis. malabohok - zekere harige plant, bohok - haar, malakopa - aan de kopa-boom doende denken. Omtrent het prefix $l i$ merkt Dunnebier voor het Bolaang-Mongondow'sch op dat het veelal verkleinende kracht heeft, vaak weer te geven met: „een „,beetje...., een weinig..., nogal...., het komt wel overeen met ons -ig ${ }^{1}$ ). In de talen der Filippijnen komt een formatief la, ook $l i$, loe, tesamen met een ander prefix voor, zonder dat de beteekenis

1) Bijdr. Kon. Inst. 85, blz. 583, vgl. blz. 461 .

D1. 101. 
of de beteekenissen duidelijk zijn. De voor het Bolaang-Mongondow'sch gegeven, met voorbeelden toegelichte verklaring past wel voor het genoemde mala-, mara-.

Het Bis. vormt ook plantennamen met mag-, b.v. magkawayan zeker grasgewas, kawayan - riet in het algemeen; magtalisay hooge boom met rechten stam, levert goed scheepstimmerhout; doet blijkbaar denken aan of heeft iets wat gelijkt op talisay - een soort amandelboom, dezelfde als of van de familie van den katapang, de Cl. 3313 ; magkoepa - als een koepa doende, zich gedragende als een koepa, den habitus van den koepa-boom hebbende, zijnde een plant die aan den koepa herinnert. 't Prefix mag- maakt den vorm krachtiger actief dan mala- (mara). Bis. kent ook een boom die malakoepa genoemd wordt, een anderen dan magkoepa. De boom waarmee vergeleken wordt, heet koepa (boom met eetbare vrucht Wb.) of makoepa (soort boom en zijn vrucht Wb.), lett. de koepa zijnde. Ik houd deze beiden voor èèn en hetzelfde. Tag. heeft alleen makoepa, niet kocpa.

In dezelfde beteekenis vindt men Tb. maha-, Tont. ma- (Tb. $h=$ Bis. g), b.v. Tb. mahalasot, mahalangsot, Tont. Malansot - een boom met bladeren die op lansat - bladeren gelijken (Wb., de Cl. 2960); Tont. makaima - een Myrtacee welker bast op die van den kaimaboom gelijkt, hierbij behoort Tb. mahakaima ${ }^{1}$ ); Tont. ma'oembi boom waarvan de vruchten op oewi - aardknollen gelijken. 't Prefix luidt hier $m a^{\prime}$-, dit doet de vraag rijzen of het in deze gevallen niet altijd $\left.m a^{\prime}-i s^{2}\right)$. Immers, de representant van de $r$ - $g$ - $h$-klank is in het Tontemboan'sch de hamza.

Het Tontemboan'sch kent nog een ander prefix ma-, thans zonder hamza, dat geheel beantwoordt aan ma- tot vorming van adjectieven in de talen der Filippijnen, het kan ook wegblijven, b.v. makapoja $=$ kapoja; masamboekow $=$ samboekow $=$ masawoekow $=$ sawoekow (de Cl. 1461 en Wb. s.v.), Tomb. heeft alleen sawoekow. Omgekeerd heeft Tomb. mawasian $=$ Tont. wasian (de Cl. 2294). Uit deze vormen blijkt dat het Tontemboan'sch hetwelk thans geen prefix bij adjectieven kent, deze vroeger bezeten heeft. Tevens dat de grondwoorden der adjectieven oorspronkelijk substantieven geweest moeten zijn. Tag. mapoeti is dus eigenlijk: witheid hebbende, vandaar: wit zijnde, wit; Bis. maayo - goedheid hebbende, goed zijnde, goed.

1) de Cl, 1355 stelt ten onrechte kaima $=$ makaima $=$ mahakaima, zie Tont. wb. s.v.v.

2) Zie S. J. Esser, Ma-, ma'-, mě-, mě'- in het Tontemboansch, Tijdschr. Bat. Gen. LXXIV, 382 v.v. 
Valt het voorvoegsel af, als b.v. in Soend. en Jav. is geschied, dan blijft het gw. met adjectivische beteekenis over, het adjectief is geboren. Secundair kunnen nu van zulke adjectieven weer substantieven gemaakt worden, b.v. met $k a-a n$ of door reduplicatie, b.v. Jav. kabětjikan - goedheid, van bětjik — goed, Soend. kokoneng dooier, van koneng-geel. In abang-rood is $a$ bewaard omdat het gw. èènlettergrepig is (bang - roode kleur) het prefix wordt niet meer als zoodanig gevoeld doch is deel van het woord geworden, zoodat abang voor den Javaan het woord is.

Het proces van het afvallen van het adjectief-prefix voltrekt zich in den tegenwoordigen tijd aan het Boegineesch en aan het Makassaarsch; b.v. Boeg. makoedara - groen, mapoete sassa - puur wit, doch: boenga poete - witte bloem. Van het Mak. zegt Cense in een nog niet gepubliceerd stuk waarvan ik wegens de bizondere omstandigheden ongevraagd gebruik maak: „Bijvoeglijke naamwoorden ,waren in een ouder stadium van het Makassaarsch allen voorzien ,,van het voorvoegsel ma-. Tegenwoordig treft men dit voorvoegsel ,nog slechts in enkele staande uitdrukkingen en bepaalde zinswen,dingen aan, b.v. lompo - groot, in: toe malompo - gouverneur, ,lett. ,groote heer"; doch in de Djajalangkara vindt men op de eerste de beste bladzijde : malompo kakaraenganna mala'ba' irateyang anging siyagāng ri bawa anging (Chr. blz. 1) - zijn rijk was groot, zoowel bovenwinds als benedenwinds uitgestrekt (breed). In het Javaansch heeft zich dit proces vóór eeuwen voltrokken, het Oud-Jav. kent nog mapoetih, apoetih ( $m a=a$-) - wit.

Van dit adjectivisch gebruik van ma- vindt men nu in vele talen die het prefix thans niet meer hebben, de sporen terug in plantennamen, zie Woordenlijst. Naast $m a$ - komt $m a-+$ prenasaleering van het gw. voor, wat evenmin verschil maakt als al of niet prenasaleering van den aanwijzer. Ook vindt men in beperkte mate $m a-+$ triller, vormelijk overeenkomende met Bis. mag-, Tont. maha- (zie boven), maar in beteekenis aan ma- en mang gelijk; b.v. M.K. marapalam $($ mara + palam $)-$ de palam zijnde $=$ ampalam $($ aanwijzer ha- + geprenasaleerd gw.) $=$ Jav. pělěm $=$ Soend. mangpělěm; Mal. martitin $=$ M.K. maratitin (de Cl. 3271); Jav. marasawa $=$ masawa $=$ sawa (de Cl. 1274); Jav. mangkoedoe $=$ koedoe.

De aksara's zijn niet alleen aanwijzer. Zij treden ook als formatieven op. Een deel, als $k a-, t a-, p a-$, is nog levend, anderen zijn versteend, als tja-, dja-, ga-, zoodat de oorspronkelijke functie niet 
394 GELIJKHEID EN VERSCHIL VOORVOEGSELS IN INDONESISCHE TALEN.

meer duidelijk is. Doch, levend of niet meer levend, dezelfde aksara's die aanwijzer zijn, vindt men als formatief terug. Er is echter in beide gevallen een groot verschil. Bij de formatieven kan verandering van klinker verandering van beteekenis meebrengen, er is verschil b.v. tusschen Boeg. pa-, pe-, po-, Tont. pa-, p̌e-, Tag. $k a-$, $k i-$ enz. En voorts heeft elke aksara, als formatief, een eigen, van alle andere als formatieven optredende aksara's onderscheiden beteekenis.

Er staat dus tegenover gelijkheid als aanwijzer verscheidenheid van dezelfde partikels als formatief.

Leiden, Juni 1941. 